УДК 74.01/.09

DOI: https://doi.org/10.31500/2309-8155.20.2020.220926
ISSN 2309-8155 (Print) / 2663-0370 (Online)

сторінки/pages 69-86

\author{
Ольга Сіткарьова \\ кандидат архітектури \\ провідний науковий співробітник \\ Інститут проблем сучасного мистецтва \\ НАМ України

\section{Olga Sitkaryova} \\ PhD in Architecture \\ leading research \\ Modern Art Research Institute \\ of the National Academy of Arts of Ukraine
}

sitkaryova@mari.kiev.ua orcid.org/0000-0002-5815-6417

\title{
ДО ІСТОРІЇ ФОРМУВАННЯ КЛАДОВИЩ КИЄВО-ПЕЧЕРСЬКОЇ ЛАВРИ В ДРУГІЙ ПОЛОВИНІ XVII - НА ПОЧАТКУ XX СТОЛІТТЯ. ПОХОВАННЯ РОДИНИ ШЕРЕМЕТЄВИХ ТА СПОРІДНЕНИХ З НЕЮ РОДИН
}

\author{
To the History of Formation of the Cemeteries \\ of the Kiev-Pechersk Lavra in the Second Half \\ of the Seventeenth - Early Twentieth Century. \\ Burial of the Sheremetyev Family and Related Families
}

\begin{abstract}
Анотація. На основі архівних матеріалів досліджена історія формування кладовищ Києво-Печерської лаври в другій половині XVII - на початку XX століття. 3'ясовано, що в Успенському соборі монастиря, а також на кладовищах Дальніх та Ближніх печер поховано багато представників родини Шереметєвих та споріднених $з$ ними родин.

Ключові слова: Києво-Печерська лавра, Успенський собор, поховання, кладовище Дальніх печер, кладовище Ближніх печер.
\end{abstract}

Постановка проблеми. Питання щодо формування некрополів Києво-Печерської лаври є важливою і водночас недостатньо дослідженою темою в історії монастиря. Кожний період в історії Лаври залишив свій слід не тільки в архітектурі, живопису, декоративноприкладному мистецтві, а й на його кладовищах. В XI-XII століттях, коли в монастирі виникли кладовища у печерних лабіринтах та почав формуватися некрополь Успенського собору, тут спочили перші лаврські преподобні та давньоруські князі й їх родичі. У XIVму - на початку XVII столітті в храмі були поховані київські та інші князі, які посідали помітне місце у Великому князівстві Литовському та Руському. У $1620-1640-x$ роках в Успенському соборі ховали переважно відомих українських церковних діячів та просвітителів, а також православну шляхту. За часів Гетьманщини на кошти козацької старшини на території монастиря замість кількох дерев'яних церков будуються кам'яні храми. В деяких 3 них були поховані їх фундатори.

Після підписання 1654 року Переяславської угоди між гетьманом Богданом Хмельницьким та московським царем в багатьох українських містах з'явилися московські воєводи та різні чиновники, призначені царем. Тут постійно дислокувалися московські гарнізони, які очолювала велика кількість військових різних чинів. Багато 3 них отримали на Україні значні володіння. Сюди вони пере- везли свої родини. Якщо хтось 3 них помирав, то ховали їх, переважно, на кладовищах українських церков. Оскільки Києво-Печерська лавра була святинею для всіх православних вірян, то завжди було багато бажаючих бути похованим саме на їі кладовищах. 3 цього часу переважна більшість поховань в монастирі стала належати московитам. Серед них було багато родичів бояр Шереметєвих, які були пов'язані шлюбними зв'язками 3 численними іншими родинами Московії. Завдяки традиції бути похованими біля своїх родичів, яка не згасала 3 часом, на кладовищах Києво-Печерського монастиря з'явилися поховання внуків, правнуків та інших родичів зазначених осіб, що визначило особливості формування некрополя Лаври в зазначений період. Проте персональний склад похованих тут осіб, їх біографічні дані та родинні зв’язки, місця розташування могил, типи та стилі надгробків досі досліджені недостатньо. Стаття присвячена похованням в Лаврі родини Шереметєвих, представників якої ховали в монастирі понад три століття.

Аналіз останніх досліджень і публікацій. Питання щодо поховань в Києво-Печерській лаврі досліджувалося у зв'язку з відтворенням Успенського собору. Тоді були підготовлені історичні довідки 3 питань архітектури, живопису, декоративно-прикладного мистецтва та некрополю храму, а також видана монографія «Успенський собор Києво-Пе- 
черської лаври. До історії архітектурно-археологічних досліджень та проекту відбудови", в яких були узагальнені всі дослідження попередніх часів. Зазначені матеріали були використані при розробці проекту відтворення собору, який у 2000-х роках реалізований в натурі [1]. Нова інформація про кладовище Успенського собору була отримана під час археологічних досліджень, виконаних у 1986му - на початку 2000-х років, яка міститься у звітах про розкопки, виконані під керівництвом В. О. Харламова [2], Г. Ю. Івакіна, С. А. Балакіна. Вона оприлюднена у статтях вищезгаданих дослідників, в тому числі: «Поховання Павла II Конюскевича в Успенському соборі Києво-Печерської лаври» [3], «Поховальний комплекс XV ст. у нартексі Успенського собору Києво-Печерської лаври» [4] Г. Ю. Івакін, С. А. Балакін). Звертаючись до цієї теми, деякі дослідники оприлюднили низку статей, в тому числі: В. В. Ластовський «До питання про поховання Остафія Дашковича в Успенському соборі Києво-Печерської лаври» [5], О. Д. Козак «Палеопатологические исследования погребений некрополя Успенского собора Киево-Печерской лавры» [6], О. Д. Козак, Н. С. Козак «Поховання в порталі Успенського собору КиєвоПечерського монастиря. До питання про інославні покаянні практики в Древній Русі» [7], О. В. Сіткарьова «До питання про надмогильні плити некрополя Успенського собору КиєвоПечерської лаври» [8], "До питання дослідження некрополя Успенського собору КиєвоПечерської лаври: Поховання Г. І. Вердеревського, П. Г. Лещинської, М. О. Глєбової» [9], «Матеріали до відтворення інтер'єра Стефанівського приділа Успенського собору КиєвоПечерської лаври» [10]. В праці О. Чумаченко «Образи з минулого" [11] узагальнені відомості щодо похованих в головному храмі монастиря осіб. Усі вищезазначені роботи стосувалися некрополя Успенського собору. Кладовища Дальніх та Ближніх печер досліджувала Л. А. Проценко в працях: «Історія київського некрополя» та «И до небес рукой подать» [12]. Окремим особам, які спочили на території монастиря, присвячені статті Т. О. Лисенко [13], Р. Качана [14] та інших. Похованням членів родини Шереметєвих в Успенському соборі присвячена стаття О. Чумаченко «Родинні поховання Шереметєвих в Києво-Печерській лаврі» [15], проте в ній згадуються далеко не всі особи, які тут спочили.

Мета дослідження - простежити хід формування некрополя монастиря в другій половині XVII - на початку XX століття, з'ясувати, хто $з$ родичів Шереметєвих спочив у Києво-Печерській лаврі та їх родинні зв'язки з особами, які поховані в Києво-Печерській лаврі.

Виклад основного матеріалу. Історія поховань в Києво-Печерському монастирі членів родини Шереметєвих розпочинається незабаром після підписання 1654 року Переяславської угоди між гетьманом Богданом Хмельницьким та московським царем Олексієм Михайловичем. Тоді в Києві, а потім в усіх великих українських містах з'явилися воєводи та інші урядові чиновники та військові, призначені сюди з Москви. Серед них бачимо кілька представників родини Шереметєвих. Одним з перших сюди прибув 1658 року на чолі московського війська боярин та намісник новгородський Василь Борисович Шереметєв (1622-1682). Тоді московське військо мало придушити спробу прибічників гетьмана Івана Виговського розірвати стосунки з Московією. 1660 року після поразки під Любарем та оточення війська В. Б. Шереметєва під Чудовом він потрапив у полон, де перебував багато років [16].

Пізніше кілька членів родини Шереметєвих були київськими воєводами, а потім генерал-губернаторами. Так, у 1666-1669 роках воєводою у Києві був боярин, намісник смоленський Петро Васильович Великий Шереметєв (?-1709) [17, с. 120, 121], у 1684-1686 роках боярин та намісник кондійський Федір Петрович Шереметєв [17, с. 125, 127], а в 1730-1737київський губернатор генерал-лейтенант Володимир Петрович Шереметєв (1668-1737) [18]. 3 Києвом тісно пов'язане життя генералфельдмаршала (з 1701 року) Бориса Петровича Шереметєва (1652-1719).

Тривалий час перебуваючи на Україні, Шереметєви перевозили сюди свої родини. Спілкування з іншими родинами іноді закінчувалося шлюбами між деякими їх членами. Шлюбну стратегію багато в чому визначало бажання родин зміцнити своє становище в суспільстві та владних структурах. Невипадково, що часто члени споріднених родин займали посади київських воєвод змінюючи один одного.

Шереметєви здавна були споріднені 3 такими відомими та впливовими родинами, як Пожарські, Морозови, Долгорукови, Голіцини, Салтикови. Так, боярин Іван Петрович Шереметєв (+1647) був першим чоловіком $\epsilon_{\mathrm{B}}$ докії Петрівни Пожарської (+1671), доньки Петра Дмитровича Пожарського (+1648). Другім її чоловіком був Юрій Олексійович Долгоруков (в ченцях Софоній) (+1682), який в першому шлюбі був одружений з Оленою Василівною Морозовою $(+1666)$. Коло шлюбних зв'язків Шереметєвих в подальші часи постійно розширювалося.

Вищезгаданий київський воєвода Петро Васильович Шереметєв був одружений $3 \mathrm{AH}-$ ною (Федосією) Федорівною Волинською.

Інший київський воєвода, Федор Петрович Шереметєв, був одружений тричі: з Пелагією Іванівною Самойлович (?-1685) - донькою гетьмана Івана Самойловича та Марії Іванівни Голуб (1640-?); з княгинею ЛобановоюРостовською (уродж. Соковніною), а також 3 княгинею Анастасією Петрівною Голіциною (уродж. Прозоровською) (1665-1729), донькою боярина князя Петра Івановича Прозоровського, вдовою князя Івана Олексійовича Голіцина (1651-1722) [19, с. 134].

Борис Петрович Шереметєв був одружений двічі: з Євдокією Олексіївною Чіріковою, 
донькою Олексія Прокоповича Чірікова та Федосії Павлівни Сомової, а в другому шлюбі 3 Анною Петрівною Салтиковою (1677-1728) вдовою рідного брата матері Петра I Льва Кириловича Наришкіна (1664-1705).

Батьком Анни Петрівни Салтикової був боярин Петро Петрович Салтиков (?-1700) [19, с. 281], а матір’ю - Марфа Іванівна Прозоровська (1658-1730) - рідна сестра Петра Івановича Прозоровського, який був батьком третьої дружини Федора Петровича Шереметєва - Настасії Петрівни Прозоровської (16651729). Ім'я та по батькові другої дружини Федора Петровича Шереметєва, княгині Лобонової-Ростовської (уродж. Соковніної), а також те, хто був її батьками та першим чоловіком, потребують додаткового дослідження. Не з'ясовано й те, хто був батьками Анни (Федосії) Федорівни Волинської. Але відомо, що представник родини Волинських - намісник бельський Іван Волинський був київським воєводою з 1681 року, змінивши на цій посаді Петра Васильовича Великого Шереметєва.

Таким чином, у другій половині XVII століття члени родини Шереметєвих, направлені на службу до Києва московським урядом, були через свої шлюби споріднені з родинами: Волинських, Самойловичів, Голіциних, Прозоровських, Лобанових-Ростовських, Соковніних, Чірікових, Сомових, Салтикових, Наришкіних. Деякі члени цих родин були поховані на кладовищах найбільш шанованого для всіх православних Києво-Печерського монастиря. Пізніше біля них ховали їх родичів, що значною мірою обумовило специфіку формування некрополю Києво-Печерської лаври.

Серед перших поховань осіб, причетних до родини Шереметєвих, було поховання тестя Б. П. Шереметєва - Олексія Пантелеймоновича Чірікова. Відомо, що майбутній генерал-фельдмаршал вперше одружився близько 1669 року у віці 17 років. У цей час (в 1666-1669 роках) його батько Петро Васильович Великий Шереметєв був київським воєводою. Мати дружини Бориса Петровича - Федосія Павлівна Сомова була донькою дворянина Павла Семеновича Сомова. Ії родина доводилася родичами Федору Михайловичу Ртищеву (16251673), який належав до найближчого оточення царя Олексія Михайловича. Батько майбутньої дружини Б. П. Шереметєва - Олексій Пантелєймович Чіріков - був стольником. Він два роки служив у Саратові, а 1658-го був призначений воєводою у Полтаву. На початку 1665 року його викликали до Москви, де за якусь провину жорстоко покарали - «бито батогами» [20]. Вірогідно, тоді О. П. Чіріков отримав каліцтво, оскільки після повернення на Україну на посаду воєводи в Переяслав прожив лише чотири роки та перед смертю сильно хворів. 1666 року, коли київським воєводою було призначено П. В. Шереметєва, Чірікову довелося з ним часто спілкуватися. Взаємовідносини між родинами двох воєвод були не тільки службовими. Незабаром син київського воєводи Борис Петрович обручився 3 донькою Чірікова Євдокією Олексіївною. 1668 року через хворобу Олексія Пантелеймоновича стан справ у переяславському воєводстві став незадовільним, тому на його місце була призначена інша людина, а 1669 року Чіріков помер [21]. Олексій Пантелеймонович Чіріков не дожив кілька місяців до весілля своєї доньки з Борисом Шереметєвим. Він був похований, ймовірно, біля Успенського собору. Тут, можливо, пізніше спочила й його дружина Федосія Павлівна Сомова.

\section{***}

Наступне з відомих поховань членів родини Шереметєвих в Києво-Печерській лаврі сталося в березні 1685 року, коли померла перша дружина Федора Петровича Шереметєва - донька гетьмана Івана Самойловича Пелагея (за іншими - Параскева) Іванівна Самойлович. Вона, ймовірно, була похована в склепі, влаштованому в одній із капличок, прибудованих до західного фасаду Успенського собору. У своєму щоденнику очевидець події, шотландець за походженням, генералмайор Патрик Гордон фон Ахлеуріс, який в 1679-1686 роках служив у Києві, написав: "Коли всі погребальні иеремонії було закінчено, тіло (Пелагії - О. С.)... було винесено з церкви (Успенського собору - O. С.) i перенесене на місце поховання, в маленький, щойно збудований склеп, надгробком над яким мала стати частина монастирської стіни (стіни Успенського собору - О. С.) [22; 23, с. 80-81]. У зв'язку з цим становлять інтерес гравюри, що датуються 1676 та 1693 роками: титул книги «Огородок Марії Богородиці» (1676) та гравюра з книги «Пречестные Акафисты» (1693). На першій $з$ них на західному фасаді храму ліворуч від головного входу до нього бачимо невелику каплицю, а на другій гравюрі капличок вже дві. В другій каплиці, ймовірно, й поховали небіжницю.

У червні цього ж року у зазначеному склепі поруч з Пелагеєю (Параскевою) Іванівною Шереметєвою були поховані її брат старший син Івана Самойловича стародубський полковник Семен Іванович Самойлович (1660-1685) та його малолітній син, який народився від шлюбу гетьманича з Марією Федорівною Сулимой (бл. 1665-1705?) [24]. У щоденнику Патрика Гордона є вказівка на місце їнього поховання: «27 червня... траурна проиесія супроводжувала його (тіло померлого полковника - О. С.)... I прямувала в Печерський монастир, де по обідні, проповіді і відспівуванні померлий син гетьмана був похований поруч зі своєю сестрою. Тіло сина небіжчика, хлопчика років 4-х, який незадовго до того помер, весь час було несено попереду і поховано разом з тілом батька».

На спомин душ дочки, сина та онука гетьман I. С. Самойлович в 1686 році зробив коштовні вклади до ризниці Успенського собору: золоті дискос, звіздицю та потир, оздоблений 
фініфтю та коштовним камінням [25; 26, с. $73-$ 74], а також «Євангеліє» в коштовній оправі. Незабаром I. С. Самойлович був репресований та помер у засланні в Сибіру. Половину гетьманської казни московський уряд конфіскував.

\section{***}

У Бориса Петровича Шереметєва від першого шлюбу з Євдокією Олексіївною Чіріковою народилося дві доньки: Софія (1671-1694) та Анна Борисівна (1673-1732), а також син Михайло Борисович Шереметєв (1672-1714).

В 1694 році Б. П. Шереметєв зазнав три важкі втрати. Цього року померла його перша дружина Євдокія Олексіївна Чірікова. Точна дата її смерті невідома, але з огляду на те, що, як свідчать джерела, її чоловік був вдовим 15 років, а в 1711 році у нього народився син від другого шлюбу, Євдокія Олексіївна померла близько 1694 року. Поховали іiї, ймовірно, біля її батьків, тобто в Києво-Печерській лаврі, на кладовищі Успенського собору.

Цього ж року померла старша донька Б. П. Шереметєва Софія Борисівна 1671-1694) та її чоловік князь Семен Микитич Урусов (?1694) - син боярина Микити Семеновича Урусова та княжни Єфимії Григорівни Щербатової. Боярин Микита Семенович Урусов в 16791680 роках обіймав посаду київського воєводи. Коли померли дружина, дочка та зять Б. П. Шереметєва, він був білгородським воєводою та керував військом на кордонах з Кримським ханством. Його родина мешкала, без сумніву, десь поруч з місцем його служби, скоріш за все в Білгороді або Києві. Тому є підстави вважати, що поховали померле подружжя - доньку та сина двох бояр: Шереметєва та Урусова в найбільш шанованому православному монастирі - Києво-Печерській лаврі поруч із іншими родичами Софії Борисівни Шереметєвої.

\section{***}

У 1714 році генерал-фельдмаршал Б. П. Шереметєв поховав в Успенському соборі свого старшого сина Михайла Борисовича (16721714). Як відомо, під час Прутського походу 1711 року генерал-фельдмаршал разом з сином брав в ньому участь. Похід, яким керував особисто Петро I, закінчився поразкою. У життя родини Шереметєвих ця подія увійшла трагічною сторінкою. За умовами укладання мирної угоди 3 Османською Імперією до турків було відправлено кілька іменитих заложників. Серед них був й син Б. П. Шереметєва, який офіційно вважався головнокомандуючим армією Московщини. В полоні Михайло Борисович підірвав своє здоров'я й, повертаючись 3 Туреччини, помер. Його поховали в Печерському монастирі біля діда, бабусі, матусі, рідної сестри та ї̈ чоловіка. Про його поховання в Лаврі свідчить в своєму «Щоденнику» Яків Андрійович Маркович: «Послы иарского величества Петр Павлович Шафиров, Толстой, Бестужий и Михайло Борисович Шереметев, отпущены от Портив отоманской, по учинению мирных договоров, одколь поворочаючи, Михайло Борисовичъ Шереметев в дорозе помер и тело его припроважено до Киева, и поховано в манастиру Печерском» [29]. Поховали М. Б. Шереметєва, вірогідно, в Успенському соборі. Коштом його батька до іконостасу головного вівтаря храму були виготовлені розкішні срібні царськи врата [30].

Михайло Борисович Шереметєв був одружений з Євдокією Григорівною Наришкіною [1675-1739], донькою Григорія Філімоновича Наришкіна, двоюрідною сестрою Наталі Кирилівни Наришкіної. Вона пережила чоловіка на 25 років. Де вона похована, невідомо. Подружжя мало сина Олексія Михайловича Шереметєва 1694- 1734), який помер раніше за матір. Він був одружений з Марією Андріївною Наришкіною й від цього шлюбу народилося три сини: Микола, Федір та Сергій Олексійовичі Шереметєви. Сергій Олексійович Шереметєв (1721-1769) був одружений з Настасію Степанівною Новосільцевою (уродж. Барятинською) та мав від шлюбу з нею двох синів: Олексія та Михайла (+1821) Сергійовичів. Олексій Сергійович Шереметєв був одружений з Надією Яківною Зубатовою (+1816). У подружжя був син Микола Олексійович (+1847), одружений з Катериною Іванівною Яковлевою, та донька - Анастасія Олексіївна Шереметєва, пошлюблена з Олекс. Павловичем Долгоруковим (+1823).

\section{***}

17 лютого 1719 року помер й сам Б. П. Шереметєв. У своєму заповіті, складеному ще 20 березня 1718 року, він прохав поховати себе в Києво-Печерському монастирі. Проте в квітні цього ж року в Лаврі сталася пожежа, під час якої Успенський собор та інші споруди навколо нього суттєво постраждали та вимагали тривалого ремонту. Це було однією з причин, чому генерал-фельдмаршала поховали в СанктПетербурзі в невеликій дерев'яній Благовіщенській церкві, спорудженій в 1712-1713 роках на лівому березі Чорної річки р. Монастирці). Згодом там з'явилися споруди майбутньої Олександро-Невської лаври [31]. Зазначена церква не дійшла до нашого часу, але зберігся надгробок з поховання Б. П. Шереметєва у вигляді мідної позолоченої плити, покладеної на кам'яну основу. Зараз його можна побачити в Лазаревській усипальні Олександро-Невської лаври.

Друга дружина Б. П. Шереметєва - Анна Петрівна Салтикова (1677-1728) - пережила свого чоловіка на дев'ять років. Вона, без сумніву, була похована біля чоловіка в зазначеній Благовіщенській церкві. Надмогильна плита з її поховання теж зберіглася до нашого часу, але ії помилково атрибутують як поховання онуки генерал-фельдмаршала, доньки його сина Петра Борисовича, теж Анни Петрівни Шереметєвой [32]. Помилка бере початок з перекрученої інформації в описі зазначених надгробків 1797 року в книзі Б. Кампенгаузена [33]. В ньому автор пише: «Между захороне- 
ниями многих персон, чьи эпитафии отчасти находятся на стенах (Лазаревської усипальні - О. С.), бросаются в глаза лишь гробницы графа Петра (підкреслено - О. С.) Борисовича Шереметева, первого фельдмаршала Российской империи... и его дочери Анны Петровны, невесты графа Никиты Ивановича Панина. Саркофаги с вызолоченными досками на крышках, с надписями и гербами стоят почти в середине иеркви ...». Як відомо, Петро Борисович Шереметєв не був генерал-фельдмаршалом й похований він в Знаменській церкві Новоспаського монастиря у Москві.

\section{***}

Друга донька Б. П. Шереметєва від першого шлюбу з Євдокією Олексіївною Чіріковой - Анна Борисівна Шереметєва (16731732/30) була пошлюблена з графом Іваном Федоровичем Головіним (1682-1708), сином однієї з наближених до Петра I осіб, першого фельдмаршала Московської держави, генерал-адмірала графа Федора Олексійовича Головіна (1650-1706). Фельдмаршал помер в м. Глухів на шляху із Москви до Києва, але поховали його в Москві в родовій усипальні на кладовищі Симонова монастиря (поховання не зберіглось). Чоловік Анни Борисівни Шереметєвої помер у віці 26 років, лише на два роки переживши батька. Поховали його, вірогідно, поруч з батьком. Вдова Івана Федоровича Головіна, донька Б. П. Шереметєва, пережила чоловіка на 24 роки. Де вона похована, встановити не вдалось, однак цілком можливо, що вона спочила поруч з чоловіком в родовій усипальні Головіних. Проте зв'язок родини з Києво-Печерською лаврою не перервався. Свідченням цього стало поховання в монастирі 1795 року праонуки цього подружжя, про що мова піде нижче.

У чоловіка Анни Борисівни Шереметєвої була сестра - Параскева Федорівна Головіна, пошлюблена з Сергієм Борисовичем Голіциним, сином Бориса Олексійовича Голіцина (1654-1714), якій був вихователем Петра I, а під час подорожі царя за кордон (1697-1698) очолював разом з Львом Кириловичем Наришкіним та князем Петром Івановичем Прозоровським московський уряд. Рідними братами Бориса Олексійовича Голіцина були: Яків Олексійович Голіцин, одружений з Євфімією Василівною Шереметєвою; Петро Олексійович Голіцин (1660-1722) - київський губернатор в 1719-1722 роках, якій помер у Києві; Іван Олексійович Голіцин (1651-1722) - перший чоловік Анастасії Петрівни Прозоровської (1665-1729), яка стала третьою дружиною Федора Петровича Шереметєва.

\section{$* * *$}

Поховавши 1685 року першу дружину, Федір Петрович Шереметєв одружився з вдовою князя Лобанова-Ростовського (уродж. Соковніною). Вона померла 1722 року. Вірогідно, її теж поховали в Києво-Печерській лаврі поруч з родичами. Підставою для такого припущення єродинні зв’язки Шереметєвих, Урусових та Соковніних.

Першою дружиною Микити Семеновича Урусова була Євдокія (Авдотья) Прокопівна, донька окольничого Прокопія Федоровича Сoковніна. Рідною сестрою княгині Євдокіі була бояриня Феодосія (в черницях Феодора) (16321674) - вдова боярина Г. I. Морозова (+ бл. 1670) - одна 3 найзаможніших жінок в Московщині. Обидві сестри увійшли в історію через відомі події, пов'язані з розколом в московській церкві за патріарха Никона. Сестри були активними послідовницями ідеолога старих церковних обрядів протопопа Авакума.

Рідні брати чоловіка Федосії Прокопівни - Михайло та Борис Івановичі Морозови - свого часу були наближеними до царської родини особами. Б. І. Морозов (1590-1661) був одружений з Анною Іллівною Милославською - рідною сестрою цариці Марії Іллівни Милославської, першої дружини царя Олексія Михайловича. Після смерті царя Михайла Федоровича, поки новий молодий цар не здобув необхідного досвіду, Б. І. Морозов в 1645-1648 роках фактично керував Московщиною.

Але після смерті в 1669 році першої дружини царя впливу на Олексія Михайловича у Морозова вже не було. Тому події у церковній сфері, до яких були причетні його вищезгадані родички-розкольниці, закінчилися для них дуже сумно. За наказом царя бояриню Морозову та княгиню Урусову (уродж. Соковніних), відправили у заслання до монастиря у Боровську, де вони 1674 року померли голодною смертю у земляній в’язниці.

Як й Урусови, родина Шереметєвих була споріднена з родиною Соковніних. Родичкою першої дружини Б. П. Шереметєва - Євдокії Олексіївни Чірікової була дружина стольника Олексія Прокоповича Соковніна (?-1697) - Тетяна Степанівна Чірікова. Остання була донькою відомого дипломата Степана Чірікова, якій в 1691-1692 роках був посланником до Персії. Чоловік Т. С. Чірікової був сином вищезгаданого Прокопа Федоровича Соковніна та рідним братом сестер-розкольниць боярині Морозової та княгині Урусової. Крім сестер, у нього був рідний брат стольник Федір Прокопович Соковнін (+ 1697).

1697 року в родині Соковніних сталася ще одна трагедія. У Олексія Прокоповича було три сини: Василь, Федір, Петро та донька, яка була пошлюблена з Федором Матвійовичем Пушкіним, сином Матвія Степановича Пушкіна. Донька рідного брата М. С. Пушкіна, Якова Степановича Пушкіна, була пошлюблена 3 думним дворянином, полковником Стремянного полку Іваном Єлисеєвичем Циклером. У 1697 році О. П. Соковнін зі своїм зятем Ф. М. Пушкіним та чоловіком його племінниці I. Є. Циклером, обговорюючи в родинному колі труднощі, пов'язані зі змінами у становищі їхніх колишніх покровителів та 3 опалою їх власної, колись дуже впливової родини, побажали Петру I смерті. Ці розмови якимось чином 
стали відомі цареві. Наслідки події були для співрозмовників трагічними. Після тортур всіх трьох було страчено [28]. Їхні родичі були позбавлені дворянства та відправлені у заслання, де цього ж 1697 року померли син Олексія Прокоповича Василь Олексійович та брат Федір Прокопович Соковнін. Де вони поховані, невідомо.

Рідний брат Г. І. та Б. І. Морозових тобольський воєвода Михайло Іванович Морозов (+ 1677) був першим чоловіком Домни Семенівни Прозоровської, члени родини якої, як і Шереметєви, і батько чоловіка Софії Борисівни Шереметєвої, Микита Семенович Урусов, призначалися в різний час київськими воєводами. Так, в 1679-1681 роках в Києві служив другий чоловік Домни Семенівни Прозоровської - окольничий боярин (з 1688 року) Іван Севастьянович Хитрово, за прізвиськом Большой Анфім (1624-1697). У 1681 році київським воєводою був боярин та намісник смоленський Петро Васильович Большой Шереметєв, а в 1682-1684 роках - рідний брат Домни Семенівни Петро Семенович Прозоровський Меньшой (+ 1690). Потім на це місце призначили боярина та намісника вологодського Олексія Петровича Салтикова, якого змінив на посаді воєводи в Києві вищезгаданий Федор Петрович Шереметєв. Деякі дослідники вважають, що Федір Петрович Шереметєв похований в Києво-Печерському монастирі [27].

\section{$* * *$}

Третя дружина Федора Петровича Шереметєва - княгиня Анастасія Петрівна Шереметєва (1665-1729) (уродж. Прозоровська), вдова князя Івана Олексійовича Голіцина (1651-1722), донька боярина князя Петра Івановича Прозоровського, померла в 1729 році [34]. Ї̈̈ дідусь, Іван Семенович Прозоровський, був рідним братом Петра Семеновича Прозоровського, який в 1682-1684 роках займав посаду київського воєводи. Батько її першого чоловіка - Олексій Андрійович Голіцин (16321694) був київським воєводою в 1675-1676 роках, а його рідний брат Михайло Андрійович Голіцин — в 1678-1679 роках. Син останнього, боярин та намісник смоленський князь Дмитро Михайлович Голіцин (1665-1737), одружений $з$ Анною Яківною Одоєвською, був першим генерал-губернатором створеної 1708 року Київської губернії [35]. Після нього київським генерал-губернатором в 1719- 1723 роках був вищезгаданий князь Петро Олексійович Голіцин, а потім - генерал-аншеф князь Іван Юрійович Трубецькой (1667-1750) - син колишнього київського воєводи Юрія Петровича Трубецького та княжни Ірини Василівни Голіциної.

Про І. Ю. Трубецького відомо, що він під час битви під Нарвою потрапив до полону й перебував там до 1718 року, поки його та генерала Автомона Михайловича Головіна (1667-1720), двоюрідного брата чоловіка Анни Борисівни Шереметєвої, не обміняли на коро- лівського фельдмаршала барона Карла-Густава Реншильда. В 1719 році Іван Юрійович Трубецький був призначений командувачем всієї кавалерії, яка перебувала на Україні. Про тривалі зв'язки родини Головіних 3 Лаврою свідчить внесок до різниці Успенського собору, зроблений 1749 року Анною Іванівною Головіною (уродж. Бутурліною) - дружиною Сергія Автомоновича Головіна.

I. Ю. Трубецький був одружений в другому шлюбі (з 1691 року) з Іриною Григорівною Наришкіною (1671-1749), яка була рідною сестрою Євдокії Григорівни Наришкіної (16751739) - дружини Михайла Борисовича Шереметєва - донькою Григорія Філімоновича Наришкіна. Останній доводився двоюрідним братом Льву Кириловичу Наришкіну - першому чоловікові Анни Петрівни Салтикової, другої дружини фельдмаршала Б. П. Шереметева.

Івана Юрійовича Трубецького змінив на посаді київського генерал- губернатора генерал-лейтенант Володимир Петрович Шереметєв [36]. Терміни перебування на зазначеній посаді вищезгаданих генерал-губернаторів дослідники подають по-різному, тому з'ясувати, хто з них керував у Києві в 1729 році, коли померла третя дружина Федора Петровича Шереметєва, важко. Проте з огляду на родинні зв'язки та посади родичів подружжя $€$ підстави припускати, що поховали її в Києві. Цілком вірогідно, Анастасія Петрівна Шереметєва (уродж. Прозоровська) (1665-1729) спочила в Києво-Печерській лаврі.

\section{***}

Від другого шлюбу Б. П. Шереметєва з Анною Петрівною Наришкіною (уродж. Салтиковою) на час його смерті залишилося п’ять малолітних дітей: Петро Борисович (1713-1788), Наталя Борисівна (1714-1771), Сергій Борисович (1715-1768), Віра Борисівна (1716-?), Катерина Борисівна (1718-1799).

Старший син генерал-фельдмаршала граф Петро Борисович (1713-1788) народився в місті Прилуки. Його хресним батьком був гетьман I. I. Скоропадський. П. Б. Шереметєв одружився 3 Варварою Олексіївною Черкаською (1711/1714-1767), донькою канцлера князя Олексія Михайловича Черкаського (1680-1742) від його другого шлюбу з Марією Юріївною Трубецькою (1696-1747). Першою дружиною О. М. Черкаського була Аграфєна (Агрипина) Львівна Наришкіна (+ 1700) донька від першого шлюбу Льва Кириловича Наришкіна, першого чоловіка матері Петра Борисовича Шереметєва.

3 Черкаськими родина Шереметєвих була здавна пов'язана тривалими родинними зв'язками. Так, відомий діяч Московії та наближена до царів особа, боярин Федор Іванович Шереметєв, був одружений з Іриною Борисівною Черкаською - донькою боярина Бориса Камбулатовича Черкаського від його шлюбу з Марфою Микитичною РомановоюЮрьевою - сестрою Філарета Микитича Ро- 
манова. Рідна сестра О. М. Черкаського, Параскева Михайлівна Черкаська була пошлюблена з братом Б. П. Шереметєва - заможним та впливовим боярином Василем Петровичем Шереметєвим. Про останнього відомо, що в 1697 році, коли на життя Петра I готувався вищезгаданий замах, його ім'я було серед кандидатів, яких змовники бажали обрати на царство [37].

Бабця Варвари Олексіївни Черкаської, Марфа Яківна Одоєвська, доводилася онукою Євдокії Федорівні Шереметєвої (+ 1671), яка була донькою боярина Федора Івановича Шереметєва та дружиною боярина, князя Микити Івановича Одоєвського (+ 1689) [38].

Один із представників цієї родини, Михайло Олегукович Черкаський, в 1679 році очолював резервне військо московитів, яке дислокувалося в Києві. Його донька - Ірина Михайлівна Черкаська, була другою дружиною Якова Федоровича Долгорукова (16391720). У подружжя була донька - Анна Яківна Долгорукова (1682-1746), пошлюблена з Олексієм Петровичем Шереметєвим. Рідний брат Якова Федоровича Долгорукого, Лука Федорович Долгоруков був воєводою у Києві в 16911693 роках. В подальшому долі родини Шереметєвих тісно переплелися з долями членів родини Долгорукових.

Від шлюбу з Варварою Олексіївною Черкаською у Петра Борисовича народилося сім дітей, з яких дорослого віку досягли троє: син обер-камергер, сенатор, граф Микола Петрович (1751-1809), а також графині Анна Петрівна (1744-1768) та Варвара Петрівна (17591824) Шереметєви. Остання стала дружиною Олексія Кириловича Розумовського (17481822) - сина гетьмана України Кирила Григоровича Розумовського.

Петро Борисович Шереметєв та його діти не були поховані в Києво-Печерському монастирі, проте тут спочили їх близькі родичі.

Так, рідна сестра чоловіка Варвари Петрівни (уродж. Шереметєвої) - Параскева Кирилівна Розумовська (1755-1808), була пошлюблена з сином генерального підскарбія, таємного радника Василя Андрійовича Гудовича (+ 1764) - генерал-фельдмаршалом Іваном Васильовичем Гудовичем (1741-1820). Останній помер у своєму маєтку Чичельник Ольгопольського повіту Подільської губернії та похований в Стефанівському приділі Успенського собору Києво-Печерської лаври. Параскева Кирилівна Розумовська доводилася праонукою Анні Кирилівні Салтиковій - другій дружині Б. П. Шереметєва.

\section{***}

Не був похований в Києво-Печерській лаврі й молодший син генерал-фельдмаршала Б. П. Шереметєва та Анни Петрівни Салтикової - гвардії ротмістр граф Сергій Борисович (1715-1768), одружений з княжною Фотінією Яківною Лобановой-Ростовськой (1715-1777), донькою Якова Івановича Лобанова-Ростовського від його другого шлюбу з княжной Ма- рією Михайлівною Черкаською. Проте ця родина підтримувала тісні стосунки з Києво-Печерською лаврою. До монастиря С. Б. Шереметєвим були зроблені коштовні внески, в тому числі вишукану срібну дарохранильницю та кіот - іконостас, виконаний 3 золота і срібла та прикрашений діамантами. Ці витвори мистецтва були евакуйовані з Києва під час Другої Світової війни, але назад не повернуті й зараз знаходяться у Москві. На прохання архімандрита Печерського монастиря коштом Сергія Борисовича в 1749 році київський золотар М. Юревич переробив царські врата головного вівтаря Успенського собору, подаровані до храму його батьком Б. П. Шереметєвим [39]. Ім'я С. Б. Шереметєва неодноразово згадується в лаврських архівних документах [40].

Одна із доньок генерал-фельдмаршала Б. П. Шереметєва від його шлюбу з Анною Петрівною Салтиковою - Віра Борисівна Щереметєва (1716-?) - стала дружиною Федора Аврамовича Лопухіна (1697-1757). Він був сином Авраама Федоровича (Іларіоновича) Лопухіна (1638-1718) - рідного брата цариці Євдокії Федорівни (в черницях Олена), першої дружини Петра I. Віра Борисівна народилася майже через 20 років після сумних подій, які сталися з родиною їі чоловіка. В 1697 році, у зв'язку із вищезгаданим замахом на життя Петра I, родина Лопухіних потрапила до опали. Тоді на царицю Євдокію Федорівну пала підозра в організації замаху, й хоч їі вину не було доведено, царську дружину примусово постригли в черниці 3 ім'ям Олена. Царський тесть - батько майбутнього чоловіка Віри Борисівни Федор Авраамович Лопухін, якого вважали лідером опозиції цареві, а також його братів послали воєводами у далекі від столиць міста.

У 1718 році у зв’язку зі справою царевича Олексія Петровича проти Лопухіних знов були висунуті звинувачення у спробі державного перевороту та замаху на життя Петра I. Тоді постраждало та було страчено багато людей. Стратили й батька майбутнього чоловіка Віри Борисівни Шереметєвої. Відтоді для родини Лопухіних надовго настали скрутні часи. Зміни на краще сталися лише після смерті Петра I та повернення до Москви цариці Євдокії Федорівни Лопухіной.

Матусею чоловіка Віри Борисівни Шереметєвої була Федосія Федорівна Ромодановська, донька князя-кесаря (з 1695 року) Федора Юрійовича Ромодановського (+ 1717), якій керував Московією, поки Петро I наприкінці XVII століття перебував у подорожі за кордоном. Її рідна сестра, княжна Ірина Федорівна Ромодановська, була пошлюблена з Василем Васильовичем Шереметєвим - сином Василя Петровича Шереметева, рідного брата Б. П. Шереметєва. Рідний брат Федосії Федорівни Іван Феодорович Ромодановський (3 1717 року - князь-кесарь), був одружений з Анас- 
тасією Федорівною Салтиковой, донькою боярина Федора Петровича Салтикова (+ 1697). Друга донька Ф. П. Салтикова - Параскева була дружиною царя Івана Олексійовича. Двоюрідна сестра майбутнього чоловіка Віри Борисівни Шереметєвої - Катерина Іванівна Ромодановська, була пошлюблена 3 Михайлом Гавриловичем Головкіним (1699-1725). Чоловік Віри Борисівни доводився племінником дійсному таємному раднику Василю Федоровичу Салтикову (1675-1730), одруженому на графині Аграфені Петрівні Прозоровській - доньці вищезгаданого Петра Семеновича Меньшого Прозоровського.

Коли Віра Борисівна Шереметєва взяла шлюб з Федором Авраамовичем Лопухіним, подружжя мешкало в своєму маєтку Ясенево неподалік від Москви, де вони побудували новий кам'яний будинок (зараз тут Центр-музей ім. Н. К. Реріха) та церкву на честь Петра і Павла 3 дзвіницею та трапезною. Коли Віра Борисівна померла і де похована, невідомо. Можливо припустити, що вона разом з чоловіком спочила на кладовищі зазначеної церкви, або іï поховали в родинній усипальні Головіних в Спасо-Андронниковому монастирі, але їх поховання не зберіглися. В цій обителі перша дружина Петра I Євдокія Лопухіна (в черницях Олена) побудувала в 1691-1694 роках у зв'язку 3 народженням сина царевича Олексія Петровича трьохярусну трьохпрестольну церкву. В церкві знаходиться родинна усипальня Лопухіних. Тут похований батько цариці Євдокії, боярин Федор Іларіон (Авраамович) Лопухін, а також його онук, рідний брат чоловіка Віри Борисівни Шереметєвої - генерал-аншеф Василь Абрамович Лопухін (1711-1757), який загинув 19 серпня 1757 року при Гросс-Егерсдорфі. В подальшому родина Лопухіних теж була тісно пов'язана з родиною Шереметєвих.

\section{***}

Ще однією донькою Б. П. Шереметєва була Катерина Борисівна Шереметєва (1718-1799), яка стала дружиною полковника Олексія Васильовича Урусова (1722-1786 ). Він був сином Василя Олексійовича Урусова (п. 1742) та княжни Параскеви Петрівни Долгорукової. Його дідом був стольник Олексій Микитович Урусов - рідний брат Семена Микитича Урусова (?-1694), одруженого з Софією Борисівною Шереметєвою (1671-1694), донькою генералфельдмаршала Б. П. Шереметєва та його першої дружини $€$.О. Чірікової.

У Катерини Борисівни та Олексія Васильовича Урусова народилися дві доньки: Анна та Варвара Олексіївни , а також син Василь Олексійович Урусов. У останнього від шлюбу з Семичевою було п'ять синів. Онук від одного 3 них, князь Олександр Михайлович Урусов (1766-1853), був одружений з Катериною Павлівною Татищевою (1768-?). Один із синів цього подружжя - генерал-лейтенант Михайло Олександрович Урусов - був одружений 3 Катериною Петрівною Єнгельгард (уродж. Татищева) (+ 1821).
У доньки фельдмаршала Б. П. Шереметєва Софії Борисівни від шлюбу з Семеном Микитичем Урусовим було два сини, один з яких не залишив нащадків, а другий, Василь Семенович, мав трьох синів. Онук одного з них - Микола Юрьєвич Урусов (+1821) був одружений з Іриною Миколаївною Хитрово (+ 1854).

\section{$* * *$}

Третя донька генерал-фельдмаршала Б. П. Шереметєва від шлюбу з Анною Петрівною Салтиковою - Наталя Борисівна Шереметєва (1714-1771) була дружиною князя Івана Олексійовича Долгорукого (1708-1739). І. О. Долгоруков був обер-камергером и майором Преображенського полку (з 1728), фаворитом Петра II. Його батьками були дійсний таємний радник, член Верховної таємної ради Олексій Григорович Долгоруков (?-1734) та Параскева Юріївна Хилкова (+ 1730). У подружжя крім Івана Олексійовича, було ще три сини: Олександр, Олексій, Микола Олексійовичі та донька Катерина Олексіївна (1712-1745). Разом з іншими родичами I. О. Долгоруков взяв участь у складанні підложної духівниці імператора на користь своєї сестри Катерини, яка незадовго до раптової смерті Петра II була оголошена нареченою імператора. Коли після смерті Петра II Долгорукови внаслідок палацових інтриг зазнали репресій, багато представників цієї родини було відправлено у заслання та страчено. Стратили сина Луки Федоровича Долгорукого - дипломата, дійсного таємного радника, члена Верховної таємної ради князя Василя Лукича Долгорукова (16701739). У засланні в Березові опинилися й там незабаром померли батьки чоловіка Наталі Борисівни. Були страчені рідні брати Олексія Григоровича Долгорукого: Іван, Олександр та Сергій Григоровичі. Відправили з батьками у Березов, а потім зачинили у монастирі в Томську його сестру Катерину Олексіївну. Зазнав катувань та був відправлений у заслання син О. Г. Долгорукого - Микола Олексійович Долгоруков (1713-1790).

1739 року стратили й чоловіка Наталі Борисівни Шереметєвої - Івана Олексійовича Долгорукова. У подружжя було два сина: Михайло та Дмитро Івановичі Долгорукови. Один 3 них, Дмитро Іванович, був хворим та з часом став ченцем. Він помер 1769 року та був похований в Києво-Печерської лаврі біля входу до Успенського собору. Його мати в 1757 році взяла чернечий постриг з ім'ям Нектарія у київському Флорівському монастирі. Черницею вона була близко 14 років. На її кошти тут побудували дерев'яну церкву Воскресіння Христова та три ділянки кам'яної огорожі навколо обителі. Нектарія передала до монастиря ікону «Презри на смирение». До Києво-Печерської лаври вона надала 1747 року коштовне церковне облачіння: фелон, стихар, єпитрахиль, які є чудовими творами декоративноприкладного мистецтва [41]. Наталя Борисівна (черниця Нектарія) померла 1771 року та похована біля Успенського собору поруч 
із сином. Над їх похованнями були покладені чавунні надмогольні плити, виготовлені на замовлення Михайла Івановича Долгорукого. Плити зберіглися до нашого часу. Як свідчить напис на плиті з поховання Дмитра Івановича Долгорукова, він помер 25 травня 1769 року.

\section{***}

На місяць раніше, в квітні цього ж року, загинув від ран, отриманих в битві під Хотином його дядько генерал-майор князь Петро Сергійович Долгоруков (1726-1769), син вищезгаданого страченого в 1739 році Сергія Григоровича Долгорукого. С. Г. Долгоруков був одружений з баронесою Марфою Петрівною Шафіровою 1697-1762). Остання була донькою віцеканцлера барона Петра Павловича Шафірова 1669-1736), якій в 1711-1714 роках разом з Михайлом Борисовичем Шереметєвим, братом Наталі Борисівни, перебував заложником в Туреччині й якому пощастило повернутися звідти живим.

П. С. Долгорукова поховали в склепі Стефаніївського приділу Успенського собору Києво-Печерської лаври. Як свідчить креслення склепу, виконане наприкінці XVIII століття, він складався із двох частин та в ньому стояло 15 надгробків у вигляді саркофагів. Оскільки креслення з'явилося через кілька років після поховання П. С. Долгорукова, на ньому зафіксовано кілька гробниць, яких на час смерті князя ще не було. Гробниця П. С. Долгорукова зображена в першій від сходів частині склепу. Тут до нього вже був похований двоюрідний брат цариці Наталі Кирилівни Наришкіної, київський генерал-губернатор Михайло Іванович Леонтьєв (+1752р.) та його дружина Марія Василівна Єварлакова (+ 1746 р.). Сестра Марії Василівни - Аграфена Василівна Єварлакова (1688-1753) була дружиною сенатора, генерал-поручика графа Івана Васильовича Паніна (1673-1736). Їх син граф Микита Іванович Панін (1718-1783), обер-гофмейстер з 1730 року, дійсний таємний радник, був заручений з графинею Анною Петрівною Шереметєвою (1744-1768) - онукою генерал-фельдмаршала Шереметєва, але наречена померла напередодні весілля.

Крім того, в склепі під Стефанівським приділом тоді спочивало кілька померлих осіб духовного сану, а також небіжчики імена, яких в той час вже не пам'ятали. До нашого часу жодна з гробниць, позначених на кресленні, в тому числі гробниця П. С. Долгорукова, не збереглися.

\section{***}

Про сумну долю родини Долгорукових дізнаємося зі спогадів княгині Н. Б. Долгорукої (родж. Шереметєвой) : "Своеручные записки княгини Натальи Борисовны Долгорукой, дочери генерал-фельдмаршала графа Бориса Петровича Шереметева" [42], а також спогадів її онука Івана Михайловича Долгорукова (1764-1823).

Іван Михайлович Долгоруков народився у другого сина Наталі Борисівни та Івана Олексійовича Долгорукова - Михайла Івановича Долгорукова від його шлюбу з баронесою Анною Миколаївною Строгановою, донькою таємного радника, дійсного камергера барона Миколи Григоровича Строганова (1700-1758) та Параскеви Бутурліної.

Дідом дружини Михайла Івановича Долгорукова був «именитий человек» Григорий Дмитрович Строганов (1656-1715), а бабцею - Марія (Васса) Яківна Новосільцева (16771733), статс-дама 31724 року. Тобто родина Шереметєвих була споріднена не тільки з родиною Долгорукових, а й з Новосільцевими та Строгановими. Невипадково, що представники зазначених родин дарували Києво-Печерській лаврі, де поховані їхні родичі, різні цінні вклади. Так, наприклад, в 1739 році рідний брат батька Анни Миколаївни Строганової, генерал-поручик, дійсний камергер барон Олександр Григорович Строганов (16981754), одружений з графинею Оленою Василівною Шереметєвою, подарував Лаврі високомистецькі шиті речі: фелон та палицю [43]. Строганови надавали вклади до обителі й в XIX столітті [44].

Князь I. М. Долгоруков (1764-1823) був володимирським губернатором, таємним радником 31804 року. Відомий він й як автор збірки автобіографічних віршів "Капище моего сердиа» та цікавих спогадів.

Він був одружений двічі. Перша його дружина (з 1787 року) - Євгенія (Ніна) Сергіївна Смирная (1770-1804), померла у віці 34 роки та похована в Донському монастирі [45]. Другою дружиною І. М. Долгорукова (з 1807 року) була удова князя Пожарського - Аграфена Олексіївна (уродж. Безобразова), донька лейб-гвардії поручика, поміщика Володимирської, Рязанської, Нижегородської, Саратовської та Тульської губерній Олексія Григоровича Безобразова (1736-1800). Від першого шлюбу Аграфена Олексіївна мала кілька синів. Її рідний брат Григорій Олексійович Безобразов був одружений $з$ Параскевою Михайлівною Долгоруковою.

Від шлюбу з Є. С. Смирною у І. М. Долгорукова народилося чотири сини та три доньки. Одна 3 доньок померла в 1810 році. Щоб притамувати біль втрати, подружжя здійснило далеку подорож, яка докладно описана у спогадах Івана Михайловича «Славны бубны за горами или путешествие мое кое-куда 1810 года» [46]. Ще одна донька I. М. Долгорукова Варвара-Антоніна Іванівна, була пошлюблена 3 таємним радником П. А. Новиковим. Хто був чоловіком їхньої третьої доньки - Марії Іванівни, з'ясувати не вдалося.

Три сини Івана Михайловича Долгорукова не залишили нащадків, в тому числі: Олександр Іванович (1793-1868), корнет у відставці, чиновник 8-го класу, письменник; Павло Іванович (1787-1845), член Попечительного комітету щодо колоністів Південного краю, одружений з 1823 року з Єлизаветою Петрівною Голіциною (1800-1863); а також Михайло Іва- 
нович. Найбільш відомим став четвертий син подружжя - Дмитро Іванович Долгоруков (1797-1867), який зробив кар'єру в дипломатичній сфері, працюючи чиновником Колегії іноземних справ. У 1820 році він був відправлений в посольство до Константинополю, де послом був його дядька дійсний таємний радник, обер-камергер, член Державної ради граф Григорій Олександрович Строганов (1770-1857). Потім Д. І. Долгоруков працював у Римі, Мадриді, Лондоні. 31831 року він був повереним у справах в Голландії, а з 1838-го в Неаполі. 31843 року призначений радником посольства у Константинополі, а 1845-го став посланником та повноважним міністром в Персії, сенатором. Він був поетом-дилетантом, членом літературно-політичного товариства «Зеленая лампа». [47].

Д. І. Долгоруков був одружений з Софією Никанорівною Хитрово. У останньої була рідна сестра Анна Никанорівна Хитрово, пошлюблена з Михайлом Михайловичем Зіновьєвим. В Києво-Печерській лаврі на кладовищі Дальніх печер біля північно-західного фасаду Аннозачатіївської церкви похована донька цього подружжя дівиця Єлизавета Михайлівна Зіновьєва (1818-1844).

У Дмитра Івановича та Софії Никанорівни були дві доньки-княжни: Євгенія та Катерина Дмитровни Долгорукови. Де вони поховані, з'ясувати не вдалося.

Крім сина Івана Михайловича, у Михайла Івановича Долгорукова та Анни Миколаївни Строганової була донька - Єлизавета Михайлівна (1766-1822). У своїх спогадах «Путешествие в Киев в 1817 году" I. М. Долгоруков докладно описав зустріч зі своєю сестрою [48]. Ця зустріч виявилася останньою. Єлизавета Михайлівна померла через п’ять років після неї, а I. М. Долгоруков на рік пізніше, у 1823 році. Єлизавета Михайлівна похована, як й ї̈ бабуся Наталя Борисівна Шереметєва, в КиєвоПечерській лаврі. Ї̈̈ могила знаходилася в саду Ближніх печер. Над її похованням родичі поклали скромну чавунну надмогильну плиту [49]. Єлизавета Михайлівна була дружиною Василя Лаврентійовича Селецького (?1830/31) - сина земського судді Ніженського повіту. У подружжя Селецьких, на відміну від подружжя Долгорукових, був єдиний син дійсний статський радник Михайло Васильович Селецький.

Стосунки між родинами Долгорукових та Селецьких були дуже близькими. Коли Іван Михайлович Долгоруков після смерті матері мав передати сестрі Єлизаветі Михайлівні частину їх родинного спадку, вона, за згодою чоловіка, відмовилася від нього на користь своїх племінниць.

Син Селецьких, Михайло Васильович, служив у Полтаві, й будучи надвірним радником і віце-губернатором, виконував 1843 року посаду полтавського цивільного губернатора, а потім був у відставці та мешкав у своєму маєтку Ковалі в Канівському повіті, яке отримав у спадок від батька. Крім того, він володів се- лом Литвенець у шести верстах від Києва [50].

Архівні джерела згадують імена й інших Селецьких, пов'язаних з Києво-Печерською лаврою, але з'ясувати їх відношення до вищезгаданих осіб поки встановити не вдалося [51].

Селецькі були родичами Синельникових. Так, син першого правителя Катеринославського намісництва [1784-1788] Івана Максимовича Синельникова (1741-1788), якого називали «правою рукою світлішого князя Г. О. Потьомкіна», - Василь Іванович Синельников був одружений 3 донькою катеринославського таємного радника Івана Яковича Селецького - Софією Іванівною Селецькою. Подружжя мало синів: Івана, Миколу та Василя Васильовичів Синельникових. Рідна сестра Софії Іванівни Селецької, Варвара Іванівна, була пошлюблена 3 катеринославським губернським маршалком Дмитром Іларіоновичем Олексієвим, який був родичем Єлизавети Михайлівни Долгорукової. Один із синів Софії Іванівни - Іван Васильович Синельников, можливо, був батьком Ольги Іванівни Синельникової, дружини похованого в Києво-Печерській лаврі генерал-майора Миколи Степановича Леонова (1824-1877), проте ця інформація потребує додаткового дослідження.

\section{***}

Дмитро Іванович Долгоруков, праонук Наталі Борисівни Шереметєвої, через свій шлюб з Софією Никанорівною Хитрово породичався 3 родиною генерал-фельдмаршала, світлішого князя Михайла Ілларіоновича ГоленищеваКутузова - Смоленського (1745-1813), оскільки дві доньки останнього були пошлюблені 3 Хитрово: Анна Михайлівна (17821818) - з генерал-майором Миколою Захаровичем Хитрово (1779-1827), а їі сестра Єлизавета Михайлівна (1783-1839) в другому шлюбі (бо її перший чоловік Тизенгаузен Федор Іванович (Фердинанд Іоганович) загинув під Аустерлицем 1805 року) - з дипломатом, повереним у справах во Флоренції, генерал-майором Миколою Федоровичем Хитрово (1771-1819). Три інші доньки генерал-фельдмаршала були пошлюблені: Параскева Михайлівна (17771844) - 3 сенатором Матвієм Федоровичем Толстим (1772-1815); Дар'я Михайлівна з обер-гофмейстером, членом Державної ради Федором Петровичем Опочиненим (17781852); Катерина Михайлівна - 3 князем Миколою Даниловичем Кудашевим (1784-1813) в першому шлюбі, якій був смертельно поранений 1813 року у битві під Лейпцигом.

В Києво-Печерській лаврі на території Ближніх печер біля Хрестовоздвиженської церкви була похована малорічна племінниця М. Д. Кудашева - донька його сестри, пошлюбленої з генерал-лейтенантом (з 1837), генерал-ад’ютантом (з 1839) Карлом Густовичем Гербелем (1788-1852) - Катерина Карлівна (1825-1834). Біля неї в 1847 році поховали іiї бабцю - Катерину Сергіївну Кудашеву (уродж. Баратову), яка взяла чернечий постриг 
3 ім'ям Єфросинія. 1830 року вона подарувала монастиреві коштовний фелон, а 1839 року на їі кошти було виконано срібні царські врата до іконостасу у вівтар на честь Архистратига Михаїла Успенського собору [52] (фелон - КПЛ-Т- 88). 1862 року біля матері був похований рідний брат М. Д. Кудашева - Сергій Данилович (1795-1862).

$* * *$

Першою дружиною рідного брата Івана Олексійовича Долгорукова, чоловіка Наталі Борисівни Шереметєвої, - бригадира Миколи Олексійовича Долгорукова (1713-1790) була Наталя Сергї̈вна Голіцина (1715-1755). У подружжя народилася донька Анастасія Миколаївна Долгорукова (+ 1810), яка стала дружиною князя Григорія Олексійовича Щербатова (1751-1810). Останній був сином Олексія Івановича Щербатова та княжни Софії Григорівни Урусової. Син Григорія Олексійовича Щербатова, Олексій Григорович, від другого шлюбу 3 Софією Степанівною Апраксіною (1798-1886) мав доньку - княжну Катерину Олексіївну Щербатову (1818-1869), яка була пошлюблена з генерал-лейтенантом (з 1855), генерал-ад’ютантом (з 1852) князем Іларіоном Іларіоновичем Васильчиковим (1805-1862). I. I. Васильчиков в червні-серпні 1850 року виконував обов'язки київського генерал-губернатора. В серпні 1852 року його призначили київським військовим губернатором, подільським та волинським генерал-губернатором. В 1852-1856 роках він був попечителем Київського учбового округу. В 1862 році його призначили командувачем військами Київського військового округу. Одночасно він став 31861 року членом Державної ради. І. І. Васильчиков помер у Києві та похований в Києво-Печерській лаврі на кладовищі Ближніх печер біля південного фасаду Хрестовоздвиженської церкви. Поруч з ним в 1869 році поховали і його дружину Катерину Олексіївну.

Першою дружиною князя Олексія Григоровича Щербатова була Катерина Андріївна Вяземська (+ 1809) - онука дійсного таємного радника князя Івана Андрійовича Вяземського від шлюбу з Марією Сергійовною Долгоруковою. Син рідного брата Катерини Вяземської - таємний радник, начальник головного управління печаті, член археографічної комісії Павло Петрович Вяземський (1820?) був одружений з Марією Аркадіївною Столипіною. Остання була родичкою похованого в Києво-Печерській лаврі, гофмейстера, голови Ради міністрів Петра Аркадійовича Столипіна (1862-1911) - сина генерала від артилерії, генерал-ад’ютанта, обер-камергера Аркадія Дмитровича Столипіна від його шлюбу 3 княжною Наталею Михайлівною Горчаковою (1827-1889).

Іл. Іл. Васильчиков доводився родичем Василю Семеновичу Васильчикову, одруженому 3 донькою останнього гетьмана України Анною (в черницях Агнія) Кирилівною Разумовською (1754-1808). Анна Кирилівна була сес- трою Олексія Кириловича Разумовського чоловіка Варвари Петрівни Шереметєвої, онуки Бориса Петровича Шереметєва, доньки його сина Петра Борисовича Шереметєва.

Одна донька А. К. Разумовської та В. С. Васильчикова - Марія Василівна Васильчикова (1779-1844) була дружиною міністра внутрішніх справ (з 1802), голови Державної ради (з 1827), канцлера по внутрішніх справах (3 1834), князя Віктора Павловича Кочубея (1768-1834). Останній доводився праонуком генеральному судді Лівобережної України в 1699-1708 роках Василю Леонтьєвичу Кочубею (бл. 1640-1708), похованому біля Трапезної церкви Києво-Печерськой лаври. У подружжя Кочубеїв була донька Наталя Вікторівна (18001854), яка в 1820 році стала дружиною графа Олександра Григоровича Строганова (17951891). Батьком останнього був барон, згодом граф Григорій Олександрович Строганов двоюрідний брат онука Наталі Борисівни Шереметєвої Івана Михайловича Долгорукова. Один із синів Віктора Павловича Кочубея церемоніймейстер Михайло Вікторович (1816-1874) помер в Києві. Він був одружений у першому шлюбі з Марією Іванівною Барятинською (1818-1843).

Друга донька А. К. Розумовської та В. С. Васильчикова - Катерина Василівна Васильчикова - була пошлюблена з дійсним статським радником князем Миколою Івановичем Вяземським.

\section{$* * *$}

У Анни Петрівни Салтикової - другої дружини Б. П. Шереметєва від її першого шлюбу 3 Львом Кириловичем Наришкіним, було два сини: Олександр Львович 1694-1746) та Іван Львович (1700-1734), а також п’ять доньок: Марія, Анна, Олександра, Агрипина (Аграфена), Параскева Львівни Наришкіни. Усі вони на час смерті другого чоловіка їх матері, Бориса Петровича Шереметєва, були вже дорослими. Жодний 3 них не був похований в Києво-Печерській лаврі, але тут спочили деякі родичі їніх нащадків.

Так, одна 3 доньок Олександра Львовича Наришкіна - Агрипина (за іншими - Аграфена) Олександрівна Наришкіна була другою дружиною віце-президента Коммерц-колегії Миколи Івановича Неплюєва (1731-1784). Останній був сином дійсного таємного радника (контр-адмірала) Івана Івановича Неплюєва (1693-1773), який в 1740-1741 роках був київським губернатором. Перша дружина I. I. Неплюєва Феодосія Федорівна Татищева похована в 1740 році в Києво-Печерському монастирі на кладовищі Дальніх печер. Другою дружиною I. I. Неплюєва була Анна Іванівна Паніна - донька генерал-майора, сенатора Івана Васильовича Паніна від його шлюбу з вищезгаданою Аграфеною Василівною Єварлаковою (1688-1753).

Братом Анни Іванівни Неплюєвої (уродж. Паніної) був граф Петро Іванович Панін (17211789), одружений в першому шлюбі з Анною 
Олексіївною Татищевою. У рідного брата останньої - майора гвардії Петра Олексійовича Татищева (1730-1810) була донька Катерина Петрівна Татищева (+ 1821), пошлюблена з генерал-майором Львом Миколайовичем Енгельгардтом - племінником Анни Богданівни Енгельгардт, яка похована в Києво-Печерській Лаврі на кладовищі Ближніх печер. На кошти Л. М. Енгельгардта в 1836 році в Санкт-Петербурзі була виконана надмогильна плита, яку встановили над іï похованням.

$* * *$

Один із синів Олександра Львовича Наришкіна - гофмаршал, обер-шенк Олександр Олександрович Наришкін (1726-1795) був одружений 3 Анною Микитичною Рум'янцевою (1730-1820), донькою сенатора, генерал-майора Микити Івановича Рум'янцева та княжни Марії Василівни Мещерської. Анна Микитична доводилася двоюрідною сестрою генералфельдмаршалу, генерал-ад’ютанту графу Петру Олександровичу Рум'янцеву-Задунайському (1725-1749), який похований в 1797 році в Успенському соборі Києво-Печерської лаври. Він був одружений $з$ кн. Катериною Михайлівною Голіциною (1724-1779), донькою генерал-фельдмаршала Михайла Михайловича Голіцина (старшого) (1675-1730) від його другого шлюбу 3 Тетяною Борисівною Куракіною (1697-1757). Рідними сестрами графа П. О. Рум’янцева-Задунайського були графині: Катерина Олександрівна, пошлюблена з генералпоручиком Н. М. Леонтьєвим; Дар'я Олександрівна (1739-1817) - в першому шлюбі дружина Вальдштейна, а в другому - дійсного таємного радника князя Юрія Микитича Трубецького (1736-1811); Параскева Олександрівна (1729-1786) - дружина генерал-аншефа, генерал-ад’ютанта, генерал-губернатора Москви Якова Олександровича Брюса. Останній був сином генерал-поручика графа Олександра Романовича Брюса від його шлюбу з княжною Анастасією Михайлівною Долгоруковою (1700-1745).

1795 року біля церкви Різдва Богородиці на кладовищі Дальніх печер Києво-Печерської лаври похована княгиня Катерина Петрівна Наришкіна (1757-1795), яка була першою дружиною бригадира, сенатора, київського віцегубернатора Василя Олексійовича Хованського (1755-1830). Катерина Петрівна народилася від шлюбу генерал-майора Петра Петровича Наришкіна (1726-1782) з Параскевою Василівною Репніною (+1793). Остання була донькою генерал-аншефа, генерал-фельдцейхмейстера, князя Василя Микитовича Репніна (1697-1748) від його другого шлюбу 3 Марією Іванівною Головіною (1707-1770). Марія Іванівна Головіна була онукою генералфельдмаршала Б. П. Шереметєва, донькою вищезгаданих Анни Борисівни Шереметєвої (1672-?) та графа Івана Федоровича Головіна (1682-1707).
У подружжя Наришкіних, крім доньки Катерини Петрівни, була ще одна донька - княгиня Наталя Петрівна (1758-1825) [53]. Катерина та Наталя Петрівни (уродж. Наришкіни) доводилися праонучками Анні Борисівні Шереметєвій. Долі сестер дослідники часто плутають [54]. Про Наталю Петрівну Наришкіну згадує у своїх віршах та спогадах I. М. Долгоруков. Він повідомляє, що вона була пошлюблена з князем Степаном Борисовичем Куракіним (1754-1805). В 1799 році подружжя розірвало шлюб. Підставою для цього був зв'язок Наталі Петрівни зі Степаном Степановичем Апраксіним. Після розлучення ії колишній чоловік одружився з іншою жінкою - Катериною Дмитрівною Ізмайловой (+ 1843), а С. С. Апраксін покинув Наталю Петрівну і одружився з княжною Катериною Володимирівною Голіциною.

У сестри Наталі Петрівни Катерини Наришкіної (+ 1795) від шлюбу з В. О. Хованським народилося три доньки: Наталя Василівна Хованська (1785-1841) - перша дружина сенатора, московського почт-директора Олександра Яковича Булгакова (1781-1863); Параскева Василівна Хованська та Софія Василїнна Хованська (1788-1812), пошлюблена з Прокопом Федоровичем Соковніним (1788-1812). Останній був нащадком вищезгаданих Соковніних, страчених та репресованих в 1697 році.

Джерела свідчать, що у Федора Прокоповича Соковніна (?-1697) була донька Ірина Федорівна Соковніна - дружина князя Федора Андрійовича Прозоровського, онука київського воєводи у 1681-1682 роках Петра Семеновича Большого Прозоровського; а також син Прокопій Федорович Соковнін. Ірина Федорівна та Прокопій Федорович, як й три сини та донька Олексія Прокоповича Соковніна, доводилися двоюрідними братами та сестрами чоловіку Софії Борисівні Шереметєвої - Семену Микитичу Урусову. В Києво-Печерській лаврі біля Успенського собору похована донька рідного брата Ірини Федорівни Прокопа Федоровича - чорниця Анастасія (1723-1763) [55].

Одним із синів страченого 1697 року окольничого Олексія Прокоповича Соковніна та Тетяни Степанівни Чірікової був Петро Олексійович Соковнін (1679-1756). Після смерті батька він був відправлений на заслання до Білгорода. В 1709 році його відновили у правах та призначили капітаном в Казанський гарнізон. 1716 року він брав участь в походах по Каспійському морю, в 1724 році переведений в Невський піхотний полк, в 1727 році став підполковником, а в 1740-му отримав чин статського радника й в 1742 році був призначений воєводою в Симбірськ. П. О. Соковнін одружився 3 Дарією Олексіївною Новосільцевою (1707-?), донькою Олексія Яковича Новосільцева від шлюбу з Анною Федорівною Брацькою. Відомо, що у подружжя був син Сергій Петрович та донька Єлизавета Петрівна Соковніни. Остання була пошлюблена з статським радником, воєводою в Симбірську (з 1745) Іваном Васильовичем Лихачевим (?-1770). 
Інтерес становить повідомлення в щоденнику Якова Марковича, яке вносить деякі доповнення до біографії Петра Олексійовича Соковніна та до складу його родини. Він згадує про шлюб солдата гвардії Семенівського полку Михайла Петровича Соковніна, сина генерал-майора у відставці Петра Олексійовича Соковніна, з Анастасією Андріївною Дуніною, донькою покійного бригадира Андрія Миколайовича Дуніна. Таким чином, П. О. Соковнін вийшов у відставку в чині генерал-майора, що згідно до "Табелю о рангах" відповідає чину дійсного статського радника. У нього від шлюбу 3 Д. О. Новосільцевою був не один, а два сини та донька. Донька взяла шлюб з I. В. Лихачевим, в якому народилося два сини: Яків та Василь Івановичі Лихачеви.

\section{$* * *$}

В Успенському соборі в 1809 році був похований генерал-фельдмаршал Олександр Олександрович Прозоровський (1732-1809) [56], який під час війни з Туреччиною 1806-1812 року очолював армію, яка дислокувалася на Дунаї й, будучи вже у поважному віці, помер у військовому таборі поблизу Мачина [57]. За бажанням генерал-фельдмаршала його останки перенесли до Києва та поховали в Києво-Печерській лаврі [58]. У 1816 році прах Прозоровського перенесли в кам'яний будинок, зведений його коштом в Печерській частині міста біля Васильківської застави, якій він заповів для утримання військових інвалідів. Тут в склепі під будинковою церквою зберігалася срібна урна із серцем генерал-фельдмаршала. У 1824 році біля нього поховали і його дружину княгиню Анну Михайлівну Волконську (1747-1824), доньку сенатора, генерал-аншефа, головнокомандуючого в Москві у 1771-1780 роках князя Михайла Микитича Волконського (1713-1786) [59].

У 1841 році прах подружжя Прозоровських перенесли із вищезазначеного будинку до башти № 3 Головної київської фортеці, яка увійшла до складу знов побудованого Васильківського укріплення. За наказом імператора Миколи I башта № 3 була названа Прозоровською.

Бажання О. О. Прозоровського бути похованим в Києві не випадкове, оскільки ця родина була здавна пов'язана з містом. В 1675 році воєводою в Києві разом з Олексієм Андрійовичем Голіциним був Василь Петрович Прозоровський. Син Олексія Андрійовича Голіцина Іван Олексійович (1622-1694) - був одружений 3 Анастасією Петрівною Прозоровською (16651729), яка після його смерті побралася з Федором Петровичем Шереметєвим, який був київським воєводою в 1684-1686 роках.
У 1679-1681 роках київським воєводою став чоловік Домни Семенівни Прозоровської, яка доводилася тіткою Василю Петровичу Прозоровському, а в 1681-1682 роках — їі рідний брат Петро Семенович Прозоровський $(+1690)$.

Останній доводився прадідом генералфельдмаршалу О. О. Прозоровському. Його дідом був Микита Петрович Прозоровський, а бабцею - кн. Марія Михайлівна Голіцина. Батьком генерал-фельдмаршала був капітанлейтенант флоту Олександр Микитич Прозоровський (+ 1740), який був одружений двічі: з Параскевою Василівною Леонтьєвою та Анною Борисівною Голіциною (1687-1772), донькою Бориса Олексійовича Голіцина. Генералфельдмаршал О. О. Прозоровський народився від другого шлюбу свого батька. Від першого шлюбу у Олександра Микитича Прозоровського народився син, якого теж назвали Олександром Олександровичем (+ 1769). Він став генерал-майором та був одружений двічі: 3 кнж. Марією Сергійовною Долгоруковою та Марією Олександрівною Головіною (+ 1770). Батьком останньої був капітан флоту Олександр Федорович Головін (1694-1731) - рідний брат Івана Федоровича Головіна (16821708), одруженого з Анною Борисівною Шереметєвою (1673-1730). У останніх народилися двоє синів: Петро та Федір Івановичі, а також донька Марія Іванівна Головіна, пошлюблена 3 генерал-фельдцейхместером князем Василем Анікітичем Репніним.

Висновки. Після підписання Переяславської угоди між гетьманом Богданом Хмельницьким та царем Олексієм Михайловичем на Україну направляються численні військові та інші чиновники. Тривалий час перебуваючи на Україні та отримуючи тут величезні маєтки, вони перевозять сюди свої родини. Якщо хтось 3 членів родини вмирав, то ховали ïx на кладовищах українських церков. Найбільш шанована Печерська обитель стала місцем останнього спокою представників родини Шереметєвих та споріднених 3 нею родин Голіциних, Лобанових-Ростовських, Чірікових, Сомових, Соковніних, Салтикових, Урусових, Щербатових, Васильчикових, Долгорукових, Наришкіних, Гудович, Селецьких, Кудашевих, Кочубеїв, Татищевих, Неплюєвих, Леонтьєвих, Єварлакових, Рум'янцевих, Репніних, Хованських, Прозоровських. Завдяки бажанню бути похованим біля своїх родичів, яке не згасало з часом, на кладовищах монастиря з’явилися поховання внуків, правнуків та інших родичів - представників зазначених родин, що визначило особливості формування некрополя Києво-Печерської лаври в другій половині XVII - на початку XX століття.

\section{Література}

1. Сіткарьова О. В. Успенський собор Києво-Печерської лаври. До історії архітектурно-археологічних досліджень та проекту відбудови. К.: Довіра, доопрацювання макету — вид. «Фенікс». С. 189. 2. Харламов В. О. Отчет о раскопках Успенского собора на территории Киево- Печерского заповедника в 1986 г. НАIА НАН України, Ф.Е. № 22016. 
3. Івакін Г. Ю., Балакін С. А. Археологічні дослідження Успенського собору у 1998 році // Археологічні дослідження на Україні у 1997-1998 рр. К., 1998. С. 78-79; Балакін С. А. Поховання Павла II Конюскевича в Успенському соборі Києво-Печерської лаври // Лаврський альманах. Києво-Печерська лавра в контексті української історії та культури. Зб. наукових праць. Вип. 19. К.: Національний Києво-Печерський історико-культурний заповідник, 2007. С. 5-17.

4. Івакін Г. Ю., Балакін С. А. Поховальний комплекс XV ст. у нартексі Успенського собору Києво-Печерської лаври // Лаврський альманах. Києво-Печерська лавра в контексті української історії та культури. Зб. наукових праць. Вип. 2. К.: Національний Києво-Печерський історико-культурний заповідник, 1999. С. 69-76.

5. Ластовський В. В. До питання про поховання Остафія Дашковича в Успенському соборі КиєвоПечерської лаври // Велика Успенська церква Києво-Печерської лаври. Слід у віках. Матеріали міжнародної наукової конференції 1-2 жовтня 2001 р. К.: Національний Києво-Печерський історико-культурний заповідник, 2003. С. 121-124.

6. Козак О. Д. Палеопатологические исследования погребений некрополя Успенского собора Киево-Печерской лавры // Велика Успенська церква Києво-Печерської лаври. Слід у віках. Матеріали міжнародної наукової конференції 1-2 жовтня 2001 р. К.: Національний Києво-Печерський історико-культурний заповідник, 2003. С. 92-95.

7. Козак О. Д., Козак Н. С. Поховання в порталі Успенського собору Києво-Печерської лаври. До питання про інославні покаянні практики в Древній Русі // Лаврський альманах. Києво-Печерська лавра в контексті української історії та культури. Зб. наукових праць. Вип. 24. К.: Національний Києво-Печерський історико-культурний заповідник, 2009. С. 5-10.

8. Сіткарьова О. В. До питання про надмогильні плити некрополя Успенського собору Києво-Печерської лаври // Мистецтвознавство України. Збірник наукових праць. Вип. 6-7. К.: Академія мистецтв України, 2006. С. 503-511.

9. Сіткарьова О. В. До питання дослідження некрополя Успенського собору Києво-Печерської лаври: Поховання Г. І. Вердеревського, П. Г. Лещинської, М. О. Глєбової // Сучасні проблеми дослідження, реставрації та збереження культурної спадщини. Збірник наукових праць 3 мистецтвознавства, архітектурознавства і культурології. Вип 2. К.: Видавничий дім А+С, 2005. С. 181-198. 10. Сіткарьова О. В. Матеріали до відтворення інтер'єра Стефанівського приділа Успенського собору Києво-Печерської лаври // Мистецтвознавство України. Artresearch of Ukraine. Щорічний науковий журнал. Вип. 18. К.: ІПСМ НАМ України, 2018. С. 143-149.

11. Чумаченко О. Ю. Образи з минулого. Біографічний довіник осіб, похованих в Успенському соборі Києво-Печерської лаври. К.: РВМП «Софія», 1999. 177 с.

12. Проценко Л. А. Некрополь; «И до небес рукой подать... Путеводитель по некрополям на Ближних и Дальних пещерах. К.: Свято-Введенский мужской монастырь. 2002. 160 с.; Проценко Л. А. Історія Київського некрополя. К.: Укрбланквидав, 1995. 413 с.

13. Лисенко I. О. Данило Михайлович Щербаківський (1877-1927). Його життя та доля // Лаврський альманах. Києво-Печерська лавра в контексті української історії та культури. Зб. наукових праць. Вип. 3. К.: Національний Києво-Печерський історико-культурний заповідник, 2001. С. 109-115.

14. Качан Р. Генерал-фельдмаршал фон дер Остен-Сакен // Інформаційний бюлетень. Національний Києво-Печерський історико-культурний заповідник. № 1/18 травня. 2009.

15. Чумаченко О. Ю. Родинні поховання Шереметьєвих в Успенському соборі та на території Києво-Печерської лаври // Велика Успенська церква Києво-Печерської лаври. Слід у віках. Матеріали міжнародної наукової конференції 1-2 жовтня 2001 р. К.: Національний Києво-Печерський історико-культурний заповідник, 2003. С. 200-206.

16. Російський державний архів давніх актів РДАДА, ф. 123. Відносини Росії з Кримом. Оп. 1, спр. 49, арк. 1; спр. 51, арк. 7; спр. 52, арк. 3; спр. 58, арк. 2; спр. 59, арк. 2, 5, 6, 7, 8, 11; спр. 60, арк. 1, 4; спр. 61, арк. 1. 1679-1680 рр.

17. Берлинський М. Ф. Історія міста Києва. К.: Наукова думка, 1991. С. 120, 121; Центральний Державний історичний архів України в м. Києві ЦДІАК, ф. 128, оп. 1 грам. спр. 7 (1664).

18. Рибаков М. О. Невідомі та маловідомі сторінки історії Києва. Кий.: 1997. С. 216, 139, 140, $142,191$.

19. Петров П. Н. История родов русского дворянства. Репр. вид. Кн. 1. М.: Современник, 1991. С. 134. 20. Барсуков А. Род Шереметевых. Кн. 6. СПб., 1892. С. 348.

21. Акты Юго-Западной России (АЮЗР). Т. 6. СПб.,1869. С. 245. № 71.

22. Тарновский С. Киев в 1684-1685 годах по описанию служилого иноземца Патрикия Гордона. K., 1875.

23. Втішний А. Київські сторінки в щоденнику Патрика Гордона // Хроніка. 2000. К., 1997.

24. Кривошея В. Генеалогія українського козацтва. Нариси історії козацьких полків. К.: Стилос, 2002. С. 235-237; ІР НБУВ, ф. 2. Спр. 13518-13635. Арк. 11-26 (копія).

25. Петренко М. 3. Українське золотарство XVI-XVIII ст. К. С. 78-79, 80, 82; ХДIM, № 5782 або НХМУ. Інв. № ДН - 5993. ЦДІАК, ф. 128, оп. 1 зег., спр. 107, арк. 1-7.

26. Сіткарьова О. В. Архітектурний ансамбль Києво-Печерської лаври та їі історичного оточення за доби гетьмана I. С. Мазепи. К.: Довіра, 2005. С.7374 .

27. Дневник Якова Марковича // Киевская старина, 1891, № 4 (апрель). С. 5; Письма и Бумаги императора Петра Великого. Т. ХІ, Вып. 1. СПб., 1887. С. 322-326; Шишков А. В. Фельдмаршалы России. М.: Вече. С. 39 . 
28. Сіткарьова О. В. Успенський собор Києво-Печерської лаври. До історії архітектурно-археологічних досліджень та проекту відбудови. К.: Довіра, Фенікс. 1999. С. 188.

29. ЦДІАЛ, СПб., Росія, ф. 815, оп. 7, од. зб. 14, арк. 31.

30. Пирятко Ю. М. Лазаревская усыпальница - памятник русской культуры XVIII-XIX веков // Памятники культуры. Новые открытия. Ежегодник (ПКНО). 1988. С. 488-489.

31.CampenhausenBAuswahltopoqrafischerMerkwurdiqkeiitendesSt/- Petersburqschen Couvernements. Th. 1. Riga. 1797. S. 11-113.

32. Павленко Н. И. Петр Великий. М.: Мысль, 1994. С. 60-64.

33. Модзалевский В. Л. Малороссийский родословник. Т. 4. К., б/г. С. 478.

34. Петров П. Н. История родов русского дворянства. Репр. вид. Кн. 1. М.: Современник, 1991. С. 134.

35. Іконников В. С. Історичні портрети. К.: Либідь. 2004. С. 130-131.

36. Киевская старина. 1894. № 5. С. 353.

37. Павленко Н. И. Петр Великий. М.: Мысль. 1994. С. 62.

38. Бобровницкая И. А. Памятник московского эмальерного искусства XVII века // Памятники культуры. Новые открытия. Ежегодник (ПКНО). 1985. С. 363-377.

39. Полюшко Г. В. Втрачені скарби лаврського музею. Пошуки і знахідки. К.: Абрис, 2001. С. 4.

40. ЦДІАК, ф.128, оп. 1 заг., спр. 84 (1747 р.), спр. 87-б (1747 р.), спр. 343 (1768 р.).

41. Вклади і вкладники Успенського собору Києво-Печерської лаври XVI - поч. XX століття (сакральні тканини і вироби з металу у зібранні Національного Києво-Печерського історикокультурного заповідника). Каталог. К.: КВІЦ. 2005; НКПІК3, КПЛ-Т-30; КПЛ-Т-134; 12. КПЛ-Т- 2675.

42. Своеручные записки княгини Натальи Борисовны Долгорукой, дочери фельдмаршала графа Бориса Петровича Шереметева // Безвременье и временщики. Воспоминания об «эпохе дворцовых переворотов» (1720-е-1760-е годы). Ленинград.: Художественная литература, 1991. С. $255-278$. 43. Вклади і вкладники Успенського собору Києво-Печерської лаври XVI - поч. XX століття (сакральні тканини і вироби з металу у зібранні Національного Києво-печерського історико-культурного заповідника). Каталог. К.: КВІЦ. 2005; ЦДІАК, ф. 128, оп. 1 заг., спр. 52-а, НКПІК3 - КПЛ-Т16, НКПІКЗ - КПЛ-Т-913.

44. ЦДІАК, ф. 128, оп. 1 заг., спр. 1379.

45. Знаменитые россияне XVIII-XIX веков. Биографии и портреты. По изданию великого князя Николая Михайловича «Русские портреты XVIII-XIX столетий». СПб.: Лениздат, 1995. С. 242, 403, 404-405; Петров П. Н. История родов русского дворянства. Репр. изд. Кн. 1. М.: Современник, 1991. C. 81.

46. Долгорукий И. М. Славны бубны за горами или путешествие мое кое-куда 1810 года. Репр. изд. «Академкнига», 2010. С. 239-241.

47. Петров П. Н. История родов русского дворянства. Репр. изд. Кн. 1. М.: Современник, 1991. С. 81. 48. Долгорукий И. М. Путешествие в Киев в 1817 году. Репр. изд. К.: Академкнига. 2009.

49. ЦДІАК, України. Селецька Єлизавета (уродж. Долгорукова), поміщиця (128-оп. 1 заг., спр. 1540 , 1822 р.); Селецький Василь, полковник (128-оп. 1 заг., спр. 1542, 1822 р.).

50. Похилевич Л. И. Сказания о населеных местностях Киевской губернии или Статические, исторические и церковные заметки о всех деревнях, селах, местечках и городах, в пределах губернии находящихся. Собрал Лаврентий Иванович Похилевич. Белая церковь: издатель Александр Пшонковский. 2007. С. 463.

51. Селецький, аудитор (ЦДІАК, ф.128, оп. 1 вотч., спр. 3284, 1770 р.); Селецький Олексій, відставний фейерверкер (ЦДІАК, ф.128, оп. 1 заг., спр. 2826, 1885 р.).

52. Сіткарьова О. В. Успенський собор Києво-Печерської лаври. До історії архітектурно-археологічних досліджень та проекту відбудови. К.: Довіра, доопрацювання макету — вид. «Фенікс». С. 189.

53. Знаменитые россияне XVIII-XIX веков. Биографии и портреты. По изданию великого князя Николая Михайловича «Русские портреты XVIII-XIX столетий». СПб.: Лениздат. 1995. С. 345.

54. Проценко Л. О. И до небес рукой подать... Путеводитель по некрополям на Ближних и Дальних пещерах Киево-Печерской лавры. К.: Свято-Введенский мужской монастирь. 2002. С. 135.

55. Ключевский В. О. Исторические портреты. С. 580-585; Матвеев А. А. Записки // Записки русских людей. СПб., 1841. С. 65.

56. ЦДІА, м. СПб., Росія, ф. 796. Оп. 90. Спр. 889.

57. Шишов А. В. Фельдмаршалы России. М.: Вече, 2007. С. 263.

58. Ситкарева О. В. Киевская крепость XVIII-XIX веков. К.: АОЗТ «ИНТЕХ», 1997. С. 109, 111, 112.

59. Записки генерал-фельдмаршала князя А. А. Прозоровского. 1756-1776. М.: Российский фонд культуры «Русский архив», 2004. С. 155, 718-721, 732.

\section{References}

1. Sitkar `ova O. V. Uspens`ky`j sobor Ky`yevo-Pechers `koyi lavry`. Do istoriyi arxitekturno-arxeologichny `x doslidzhen ` ta proektu vidbudovy`. K.: Dovira, doopracyuvannya maketu — vy`d. "Feniks». S. 189.

2. Xarlamov V. O. Otchet o raskopkax Uspenskogo sobora na terry`tory`y`Ky`evo- Pecherskogo zapovedny`ka v 1986 g. NAIA NAN Ukrayiny`, F.E. \# 22016.

3. Ivakin G. Yu., Balakin S. A. Arxeologichni doslidzhennya Uspens `kogo soboru u 1998 roci // Arxeo- 
logichni doslidzhennya na Ukrayini u 1997-1998 rr. K., 1998. S. 78-79; Balakin S. A. Poxovannya Pavla II Konyuskevy`cha v Uspens `komu sobori Ky`yevo-Pechers `koyi lavry`// Lavrs `ky`j al `manax. Ky `yevoPechers `ka lavra v konteksti ukrayins `koyi istoriyi ta kul `tury`. Zb. naukovy `x pracz . Vy`p. 19. K.: Nacional `ny`j Ky`yevo-Pechers `ky`j istory`ko-kul ‘urny`j zapovidny`k, 2007. S. 5-17.

4. Ivakin G. Yu., Balakin S. A. Poxoval `ny`j kompleks XV st. u narteksi Uspens `kogo soboru Ky`yevoPechers `koyi lavry`// Lavrs `ky`j al`manax. Ky`yevo-Pechers `ka lavra v konteksti ukrayins `koyi istoriyi ta kul `tury`. Zb. naukovy `x pracz`. Vy`p. 2. K.: Nacional `ny `j Ky`yevo-Pechers `ky`j istory`kokul turny`j zapovidny`k, 1999. S. 69-76.

5. Lastovs `ky`j V. V. Do py`tannya pro poxovannya Ostafiya Dashkovy`cha v Uspens `komu sobori Ky`yevo-Pechers `koyi lavry`// Vely `ka Uspens `ka cerkva Ky`yevo-Pechers `koyi lavry`. Slid u vikax. Materialy` mizhnarodnoyi naukovoyi konferenciyi 1-2 zhovtnya 2001 r. K.: Nacional `ny`j Ky `yevo-Pechers `ky`j istory`ko-kul `turny`j zapovidny`k, 2003. S. 121-124.

6. Kozak O. D. Paleopatology`chesky`e y`ssledovany`ya pogrebeny`j nekropolya Uspenskogo sobora Ky`evo-Pecherskoj lavri // Vely`ka Uspens `ka cerkva Ky`yevo-Pechers `koyi lavry`. Slid u vikax. Materialy` mizhnarodnoyi naukovoyi konferenciyi 1-2 zhovtnya 2001 r. K.: Nacional `ny j Ky `yevo-Pechers `ky`j istory`ko-kul ‘urny`j zapovidny`k, 2003. S. 92-95.

7. Kozak O. D., Kozak N. S. Poxovannya v portali Uspens`kogo soboru Ky`yevo-Pechers `koyi lavry`. Do py ‘tannya pro inoslavni pokayanni prakty`ky`v Drevnij Rusi // Lavrs `ky`j al `manax. Ky`yevo-Pechers `ka lavra v konteksti ukrayins `koyi istoriyi ta kul `tury`. Zb. naukovy`x pracz`. Vy`p. 24. K.: Nacional `ny`j Ky`yevo-Pechers `ky`j istory`ko-kul ‘urny`j zapovidny`k, 2009. S. 5-10.

8. Sitkar `ova O. V. Do py ‘tannya pro nadmogy`l`ni ply ‘ty`nekropolya Uspens `kogo soboru Ky `yevoPechers `koyi lavry`// My`stecztvoznavstvo Ukrayiny`. Zbirny`k naukovy`x pracz`. Vy`p. 6-7. K.: Akademiya my`stecztv Ukrayiny`, 2006. S. 503-511.

9. Sitkar `ova O. V. Do py`tannya doslidzhennya nekropolya Uspens `kogo soboru Ky`yevo-Pechers `koyi lavry`: Poxovannya G. I. Verderevs `kogo, P. G. Leshhy`ns `koyi, M. O. Glyebovoyi // Suchasni problemy` doslidzhennya, restavraciyi ta zberezhennya kul `turnoyi spadshhy `ny`. Zbirny `k naukovy ` $\mathrm{x}$ pracz ` $\mathrm{z}$ my`stecztvoznavstva, arxitekturoznavstva i kul `urologiyi. Vy`p 2. K.: Vy`davny`chy`j dim A+S, 2005. S. 181-198.

10. Sitkar `ova O. V. Materialy` do vidtvorennya inter'yera Stefanivs `kogo pry `dila Uspens `kogo soboru Ky`yevo-Pechers `koyi lavry`// My`stecztvoznavstvo Ukrayiny`. Artresearch of Ukraine. Shhorichny`j naukovy`j zhurnal. Vy`p. 18. K.: IPSM NAM Ukrayiny`, 2018. S. 143-149.

11. Chumachenko O. Yu. Obrazy` z my`nulogo. Biografichny`j doviny`k osib, poxovany`x v Uspens `komu sobori Ky`yevo-Pechers `koyi lavry`. K.: RVMP «Sofiya», 1999. 177 s.

12. Procenko L. A. Nekropol `; «Y` do nebes rukoj podat `... Putevody` tel` po nekropolyam na Bly`zhny `x y`Dal `ny`x peshherax. K.: Svyato-Vvedensky `j muzhskoj monastir` . 2002.160 s.; Procenko L. A. Istoriya Ky`yivs`kogo nekropolya. K.: Ukrblankvy`dav, 1995. $413 \mathrm{s.}$

13. Ly`senko I. O. Dany`lo My`xajlovy`ch Shherbakivs`ky`j (1877-1927). Jogo zhy`ttya ta dolya // Lavrs `ky`j al`manax. Ky `yevo-Pechers `ka lavra v konteksti ukrayins `koyi istoriyi ta kul `tury`. Zb. naukovy`x pracz`.Vy`p. 3. K.: Nacional `ny`j Ky`yevo-Pechers `ky`j istory`ko-kul `turny`j zapovidny`k, 2001. S. 109-115.

14. Kachan R. General-fel `dmarshal fon der Osten-Saken // Informacijny `j byuleten `. Nacional `ny`j Ky `yevo-Pechers `ky`j istory`ko-kul ‘urny`j zapovidny`k. \# 1/18 travnya. 2009.

15. Chumachenko O. Yu. Rody`nni poxovannya Sheremet `yevy`x v Uspens `komu sobori ta na tery`toriyi Ky`yevo-Pechers `koyi lavry`// Vely`ka Uspens `ka cerkva Ky`yevo-Pechers `koyi lavry`. Slid u vikax. Materialy` mizhnarodnoyi naukovoyi konferenciyi 1-2 zhovtnya 2001 r. K.: Nacional`ny`j Ky`yevo-Pechers `ky`j istory`ko-kul `turny`j zapovidny`k, 2003. S. 200-206.

16. Rosijs `ky`j derzhavny `j arxiv davnix aktiv RDADA, f. 123. Vidnosy`ny` Rosiyi z Kry`mom. Op. 1, spr. 49, ark. 1; spr. 51, ark. 7; spr. 52, ark. 3; spr. 58, ark. 2; spr. 59, ark. 2, 5, 6, 7, 8, 11; spr. 60, ark. 1, 4; spr. 61, ark. 1. 1679-1680 rr.

17. Berly`ns`ky`j M. F. Istoriya mista Ky`yeva. K.: Naukova dumka, 1991. S. 120, 121; Central `ny`j Derzhavny`j istory`chny`j arxiv Ukrayiny`v m. Ky`yevi CzDIAK, f. 128, op. 1 gram. spr. 7 (1664).

18. Ry`bakov M. O. Nevidomi ta malovidomi storinky`istoriyi Ky`yeva. Ky`j.: 1997. S. 216, 139, 140, 142, 191.

19. Petrov P. N. Y`story`ya rodov russkogo dvoryanstva. Repr. vy`d. Kn. 1. M.: Sovremenny `k, 1991. S. 134. 20. Barsukov A. Rod Sheremetevix. Kn. 6. SPb., 1892. S. 348.

21. Akti Yugo-Zapadnoj Rossy`y`(AYuZR). T. 6. SPb.,1869. S. 245. \# 71.

22. Tarnovsky`j S. Ky`ev v 1684-1685 godax po opy`sany`yu sluzhy`logo y`nozemcza Patry`ky ya Gordona. K., 1875.

23. Vtishny`j A. Ky`yivs`ki storinky`v shhodenny`ku Patry`ka Gordona // Xronika. 2000. K., 1997.

24. Kry vosheya V. Genealogiya ukrayins `kogo kozacztva. Nary`sy`istoriyi kozacz `ky`x polkiv. K.: Sty`los, 2002. S. 235-237; IR NBUV, f. 2. Spr. 13518-13635. Ark. 11-26 (kopiya).

25. Petrenko M. 3. Ukrayins `ke zolotarstvo XVI-XVIII st. K. S. 78-79, 80, 82; XDIM, \# 5782 abo NXMU. Inv. \# DN - 5993. CzDIAK, f. 128, op. 1 zeg., spr. 107, ark. 1-7.

26. Sitkar`ova O. V. Arxitekturny j ansambl `Ky`yevo-Pechers `koyi lavry` ta yiyi istory`chnogo otochennya za doby`get`mana I. S. Mazepy`. K.: Dovira, 2005. S.7374 .

27. Dnevny `k Yakova Markovy`cha // Ky`evskaya stary`na, 1891, \# 4 (aprel `). S. 5; Py`s `ma y`Bumagy` 
y`mperatora Petra Vely`kogo. T. XI, Vip. 1. SPb., 1887. S. 322-326; Shy`shkov A. V. Fel `dmarshali Rossy`y`. M.: Veche. S. 39 .

28. Sitkar `ova O. V. Uspens `ky`j sobor Ky`yevo-Pechers `koyi lavry`. Do istoriyi arxitekturno-arxeologichny`x doslidzhen `ta proektu vidbudovy`. K.: Dovira, Feniks. 1999. S. 188.

29. CzDIAL, SPb., Rosiya, f. 815, op. 7, od. zb. 14, ark. 31.

30. Py `ryatko Yu. M. Lazarevskaya usipal `ny`cza — pamyatny`k russkoj kul `turi XVIII-XIX vekov // Pamyatny`ky`kul`turi. Novie otkrity`ya. Ezhegodny`k (PKNO). 1988. S. 488-489.

31.CampenhausenBAuswahltopoqrafischerMerkwurdiqkeiitendesSt/- Petersburqschen Souvernements. Th. 1. Riga. 1797. S. 11-113.

32. Pavlenko N. Y`. Petr Vely`ky`j. M.: Misl`, 1994. S. 60-64.

33. Modzalevsky`j V. L. Malorossy`jsky`j rodoslovny`k. T. 4. K., b/g. S. 478.

34. Petrov P. N. Y`story`ya rodov russkogo dvoryanstva. Repr. vy`d. Kn. 1. M.: Sovremenny `k, 1991. S. 134.

35. Ikonny`kov V. S. Istory`chni portrety`. K.: Ly`bid`. 2004. S. 130-131.

36. Ky`evskaya stary`na. 1894.\# 5. S. 353.

37. Pavlenko N. Y`. Petr Vely`ky`j. M.: Misl`. 1994. S. 62.

38. Bobrovny`czkaya Y`. A. Pamyatny`k moskovskogo эmal ernogo y`skusstva XVII veka // Pamyatny`ky`kul turi. Novie otkrity`ya. Ezhegodny`k (PKNO). 1985. S. 363-377.

39. Polyushko G. V. Vtracheni skarby` lavrs`kogo muzeyu. Poshuky`i znaxidky`. K.: Abry`s, 2001. S. 4. 40. CzDIAK, f.128, op. 1 zag., spr. 84 (1747 r.), spr. 87-b (1747 r.), spr. 343 (1768 r.).

41. Vklady`i vkladny `ky`Uspens `kogo soboru Ky`yevo-Pechers `koyi lavry`XVI — poch. XX stolittya (cakral `ni tkany`ny`i vy`roby`z metalu u zibranni Nacional `nogo Ky `yevo-Pechers `kogo istory`kokul `turnogo zapovidny`ka). Katalog. K.: KVICz. 2005; NKPIKZ, KPL-T-30; KPL-T-134; 12. KPL-T- 2675.

42. Svoeruchnie zapy`sky` knyagy `ny`Natal `y`Bory`sovni Dolgorukoj, dochery` fel `dmarshala grafa Bory`sa Petrovy`cha Sheremeteva// Bezvremen `e y`vremenshhy`ky`. Vospomy`nany ya ob «эpoxe dvorczovix perevorotov» (1720-e-1760-e godi). Leny`ngrad.: Xudozhestvennaya ly`teratura, 1991. S. 255278.

43. Vklady`i vkladny `ky`Uspens `kogo soboru Ky `yevo-Pechers `koyi lavry`XVI — poch. XX stolittya (cakral `ni tkany`ny`i vy 'roby`z metalu u zibranni Nacional `nogo Ky `yevo-pechers `kogo istory `kokul `urnogo zapovidny`ka). Katalog. K.: KVICz. 2005; CzDIAK, f. 128, op. 1 zag., spr. 52-a, NKPIKZ — KPLT-16, NKPIKZ - KPL-T-913.

44. CzDIAK, f. 128, op. 1 zag., spr. 1379.

45. Znameny `tie rossy yane XVIII-XIX vekov. By`ografy `y`y` portreti. Po y`zdany `yu vely `kogo knyazya Ny`kolaya My`xajlovy`cha «Russky`e portreti XVIII-XIX stolety`j». SPb.: Leny`zdat, 1995. S. 242, 403, 404-405; Petrov P. N. Y`story`ya rodov russkogo dvoryanstva. Repr. y`zd. Kn. 1. M.: Sovremenny`k, 1991. S. 81.

46. Dolgoruky j Y`. M. Slavni bubni za goramy`y`ly` puteshestvy`e moe koe-kuda 1810 goda. Repr. y`zd. "Akademkny`ga», 2010. S. 239-241.

47. Petrov P. N. Y`story`ya rodov russkogo dvoryanstva. Repr. y`zd. Kn. 1. M.: Sovremenny`k, 1991. S. 81. 48. Dolgoruky`j Y`. M. Puteshestvy`e v Ky`ev v 1817 godu. Repr. y`zd. K.: Akademkny`ga. 2009.

49. CzDIAK, Ukrayiny`. Selecz `ka Yely`zaveta (urodzh. Dolgorukova), pomishhy`cya (128-op. 1 zag., spr. 1540, 1822 r.); Selecz `ky`j Vasy`l’, polkovny`k (128-op. 1 zag., spr. 1542, 1822 r.).

50. Poxy`levy`ch L. Y`. Skazany`ya o naselenix mestnostyax Ky`evskoj guberny`y`y`ly` Staty`chesky`e, y`story`chesky`e y`cerkovnie zametky`o vsex derevnyax, selax, mestechkax y`gorodax, v predelax guberny y` naxodyashhy`xsya. Sobral Lavrenty`j Y`vanovy`ch Poxy levy`ch. Belaya cerkov`: y`zdatel`Aleksandr Pshonkovsky`j. 2007. S. 463.

51. Selecz`ky`j, audy`tor (CzDIAK, f.128, op. 1 votch., spr. 3284, 1770 r.); Selecz `ky`j Oleksij, vidstavny`j fejerverker (CzDIAK, f.128, op. 1 zag., spr. 2826, 1885 r.).

52. Sitkar `ova O. V. Uspens `ky`j sobor Ky`yevo-Pechers `koyi lavry`. Do istoriyi arxitekturno-arxeologichny `x doslidzhen ` ta proektu vidbudovy`. K.: Dovira, doopracyuvannya maketu - vy`d. «Feniks». S. 189.

53. Znameny `tie rossy yane XVIII-XIX vekov. By`ografy `y`y` portreti. Po y`zdany `yu vely `kogo knyazya Ny`kolaya My`xajlovy`cha «Russky`e portreti XVIII-XIX stolety`j». SPb.: Leny`zdat. 1995. S. 345 .

54. Procenko L. O. Y` do nebes rukoj podat `... Putevody`tel `po nekropolyam na Bly`zhny `xy`Dal `ny `x peshherax Ky`evo-Pecherskoj lavri. K.: Svyato-Vvedensky`j muzhskoj monasty`r`. 2002. S. 135.

55. Klyuchevsky`j V. O. Y`story`chesky`e portreti. S. 580-585; Matveev A. A. Zapy`sky`// Zapy`sky` russky`x lyudej. SPb., 1841. S. 65.

56. CzDIA, m. SPb., Rosiya, f. 796. Op. 90. Spr. 889.

57. Shy`shov A. V. Fel `dmarshali Rossy`y`. M.: Veche, 2007. S. 263.

58. Sy`tkareva O. V. Ky`evskaya krepost`XVIII-XIX vekov. K.: AOZT «Y`NTEX», 1997. S. 109, $111,112$.

59. Zapy`sky`general-fel `dmarshala knyazya A. A. Prozorovskogo. 1756-1776. M.: Rossy`jsky`j fond kul `uri «Russky`j arxy`v», 2004. S. 155, 718-721, 732. 


\section{Ситкарева О. В.}

К истории формирования кладбищ Киево-Печерской лавры во второй половине XVII - В начале XX века. Захоронения семьи Шереметьевых и родственных ей семей

На основе архивных материалов исследована история формирования кладбищ Киево-Печерской лавры во второй половине XVII - в начале XX века. Выяснено, что в Успенском соборе монастыря, а также на кладбищах Дальних и Ближних пещер похоронено много представителей семьи Шереметьевых и родственных с ними семей.

Ключевые слова: Киево-Печерская лавра, Успенский собор, захоронение, кладбище Дальних пещер, кладбище Ближних пещер.

\section{Sitkareva 0. V.}

On the History of the Formation of Cemeteries of the Kiev-Pechersk Lavra in the Second Half of the 17th - early 20th century. Burials of the Sheremetyev Family and Related Families

On the basis of archival materials, the history of the formation of cemeteries of the Kiev-Pechersk Lavra in the second half of the 17th - early 20th centuries has been investigated. It turned out that many representatives of the Sheremetev family and related families were buried in the Assumption Cathedral of the monastery, as well as in the cemeteries of the Far and Near Caves.

Keywords: Kiev-Pechersk Lavra, Assumption Cathedral, burial, Far Caves cemetery, Near Caves cemetery. 